\title{
ASSESSING DYNAMICS IN THE VALUE OF ECOSYSTEM SERVICES IN RESPONSE TO LAND COVER/LAND USE CHANGES IN ETHIOPIA, EAST AFRICAN RIFT SYSTEM
}

\author{
Negussie, W. $.^{1,2}-$ WU, W. $.^{1,3^{*}}-$ Alemayehu, A. ${ }^{1,2}-$ YiRSAW, E. $^{4}$ \\ ${ }^{1}$ College of Land Management, Nanjing Agricultural University, Nanjing 210095, China \\ (e-mail:wube14@yahoo.com,asferaalem2011@yahoo.com) \\ ${ }^{2}$ Department of Natural Resources Management, Assosa ATVET College, Assosa 242, Ethiopia \\ ${ }^{3}$ National and Joint Local Engineering Research Center for Rural Land Resources Use and \\ Consolidation, Nanjing 210095, China \\ ${ }^{4}$ Department of Natural Resources Management, Dilla University, Dilla, Ethiopia \\ (e-mail: eshetu.yirsaw@yahoo.com) \\ *Corresponding author \\ e-mail:ww@njau.edu.cn; phone: +86-137-7065-1675
}

(Received 25 $5^{\text {th }}$ Feb 2019; accepted $10^{\text {th }}$ Apr 2019)

\begin{abstract}
Ecosystem services (ES) are essential to human well-being. Assessing dynamics of ES is crucial to shaping the concept of sustainable development and creating public understanding of the status of ES. This study proposes to quantify the change in ES value in response to Land cover/land use (LCLU) changes over the past 33 years in the Rift Valley Lakes Region of Ethiopia. A combined approach of LCLU classification and modified ES value coefficients was employed for quantifying the ES value. Results revealed that approximately USD196.04 $\times 10^{6}(12.4 \%)$ of ES value was lost during the study period. Although cropland experienced a dramatic expansion, the total gain in ES value of the cropland was too small to balance out the overall loss. A continuous reduction in values of specific ES functions has also occurred except for food production, biological control, and pollination service function over the last three decades, indicating an apparent deterioration of the fragile Rift Valley ecosystem. Hence, to enhance the continuous supply of ES and economic development, an integrated approach to managing land and water resources is recommended. Moreover, payment for ES is also a potential remedy for ES loss at the regional and local scale.

Keywords: combined approach, benefit transfer, modified coefficient, East Africa Rift system, average ecosystem service value, loss, water bodies, woodland, cropland
\end{abstract}

\section{Introduction}

Ecosystem services (ES) are essential to human welfare (Xu and Ding, 2018; Costanza et al., 2014; Braat and de Groot, 2012; MEA, 2005). These include regulating, provisioning, supporting, and cultural services (MEA, 2005; Costanza et al., 1997). The amount and quality of ES depend on the types of ecosystem and their status (Tolessa et al., 2017a; MEA, 2005). Each ecosystem provides distinct services that could not be substituted with another (Gashaw et al., 2018). ES are closely related with land cover/land uses (LCLU), and they alter across time and space (Xu and Ding, 2018; Schirpke et al., 2017; Tolessa et al., 2017a; Costanza et al., 2014). Land cover/land use change (LCLUC) is altering the amount and quality of ES provided by ecosystems. LCLUC is an essential landscape process (Schröter et al., 2005; Daily, 1997) designed by the interaction between the social-economical activities of human beings and the natural environment (Chang et al., 2018). 
Changes in LCLU may lead to differences in the value of ES (Locatelli et al., 2017; Polasky et al., 2011; Hu et al., 2008; Kreuter et al., 2001). It may raise the value of some services while reducing that of others, which affects the capability of the biological system to sustain human needs, indicating ecological deterioration (Polasky et al., 2011), or may cause conversely (Kindu et al., 2016). For example, studies show that the transformation of forest land to cropland increases food production while reduces the regulating services provided by the forest land (Fedele et al., 2018; Rodríguez et al., 2006; Foley et al., 2005). However, a recent land development activity in marginal grassland have effected in the conversion of ES from provisioning to regulating services as a result of natural reforestation processes (Schirpke et al., 2017; Vigl et al., 2016). Thus, the study of ES value changes caused by the change in LCLU has implications (Chen et al., 2015) through creating public awareness of the continuing LCLU dynamics and is vital to indicate the vulnerability of each ES (Cabral et al., 2016).

Monetization of ES has been promoted by numerous as a model strategy to create public alertness, provide evidence for consultations with decision makers, flag up the opportunity costs of rehabilitation and/or restoration, and assist in payments for ES (Alarcon et al., 2016; Baveye et al., 2013; de Groot et al., 2012; Nelson et al., 2009; Costanza et al., 1997). Recognising and quantifying the influence of LCLUCs on global, regional, and local ES is a practical approach to evaluating the costs and benefits to the environment and supporting sustainable land management decisions (Xu and Ding, 2018; Song and Deng, 2017; Liang et al., 2017). It also assists with devising a land use planning framework suitable for sustaining the health and sustainability of land resources (Bartkowski, 2017; Cabral et al., 2016; Jacobs et al., 2016).

The results of many studies that estimated ES value in response to LCLUC were location specific. For example, some studies reveal an overall increase in ES value (Temesgen et al., 2018; Wang et al., 2014; Sawut et al., 2013) while others confirm the opposite, i.e. a decreasing trend (Gashaw et al., 2018; Leh et al., 2013; Tolessa et al., 2017a); whereas, globally, the total net loss due to LCLUC has been estimated at USD 20.2 trillion/ year between 1997 and 2011 (Costanza et al., 2014). However, estimation of ES value change at a regional scale from the global study is challenging; in fact, a regional study of a country often results in a different yield due to various approaches and classifications. Moreover, the prevailing ES valuation in response to LCLUC is not comprehensive across the whole world due to the lack of inclusion of vast ecological regions and services (Tadesse et al., 2014; Satz et al., 2013; de Bello et al., 2010); its applicability to different regions leads to improper valuation of ES (Wang et al., 2015). Even though a number of recent works have quantified and mapped ES (e.g. Leh et al., 2013; Egoh et al., 2009; Nelson et al., 2009), despite some efforts (by Arowolo et al., 2018; Niquisse and Cabral, 2018; Gashaw et al., 2018; Temesgen et al., 2018; Tolessa et al., 2017a; Kindu et al., 2016), such studies are lacking in other regions of Africa (Leh et al., 2013; Seppelt et al., 2011) that serve as a source of the world's biodiversity.

Many regions of Africa are facing rapid and profound transformation economically, socially, and environmentally a transformation that is already endangering the long-standing conservation of its substantial natural heritage and biodiversity (Mwampamba et al., 2016). Hence, the ongoing deterioration of ecosystems occurs in many regions of the continent at the expense of the well-being 
of the coming generations (Kubiszewski et al., 2017; de Groot et al., 2012); this is particularly true for Ethiopia, which lost approximately $17.7 \%$ of its overall terrestrial ES values due to LCLUC (Sutton et al., 2016).

In Ethiopia, LCLUC is a common and ever-present phenomenon because agricultural activities mainly dominate rural landscapes, affecting ES (Tolessa et al., 2017a). Integrating LCLU and an ES value dataset can assist in detecting the areas highly susceptible to change in ES at the landscape scale and provide an avenue for land management opportunities in the future. Moreover, research works carried out on LCLUC in the country mainly focuses on the driving factors and the LCLU dynamics (Meshesha et al., 2012; Tsegaye et al., 2010; Reid et al., 2000). However, the consequence of LCLUC on a wide-range of ES is rarely attempted. Currently, there has been no estimation of the impacts of such changes at a regional scale, just a few efforts made to evaluate ES in response to LCLUC at the local scale (Gashaw et al., 2018; Temesgen et al., 2018; Tolessa et al., 2017a; Kindu et al., 2016).

The study area, the Rift Valley Lakes Region (RVLR) of Ethiopia, is situated in the Eastern part of the African Rift System, and consists of lakes, streams and wetlands with unique hydro-ecological characteristics (Jansen et al., 2007; Hengsdijk and Jansen, 2006), and a wide range of landscapes with high biodiversity. It is the largest freshwater ecosystem in the nation with considerable social, economic and ecological significance. However, the RVLR is one of the most environmentally susceptible areas in Ethiopia. Being a landlocked basin, relatively little intervention in the water and land resources can have substantial consequences for ecosystems goods and services, and weaken the potential sustainable use of the region (Ayenew, 2004; Legesse et al., 2004).

Therefore, recognising the influences of LCLUC on ES value in the study region is vital to increasing public understanding and indicating the proper land use policy direction. Previous studies emphasised potential LCLUC, although the majority were carried-out at a local scale and described the LCLUC qualitatively. The consequences of the existing LCLU and land degradation are huge, including declining crop and livestock production and exacerbated food shortages in the area (Meshesha et al., 2012). Hence, the objective of this study was 1) to characterise changes in LCLU over the last three decades and 2) to quantify and map the ES value alteration in response to LCLUC using a modified ES value coefficient in the RVLR of Ethiopia from 1986 to 2018.

This study estimates changes of ES in response to LCLUC using a conservative ES coefficient modified by (Kindu et al., 2016) using benefit transfer approach. Kindu et al. (2016) developed modified conservative value coefficients through a review of the previous studies, and dataset available from the Economics of Ecosystems and Biodiversity (TEEB) database. This value coefficient is assumed to be suitable for the RVLR of Ethiopia, which is a developing region with a rapidly growing population (Legesse et al., 2004), abundant livestock (Meshesha et al., 2012) and a vulnerable ecosystem, and for other areas with a similar landscape setting.

This paper has five sections: The first section is the introduction of the study. The second section gives a concise description of the study area, introduces methods to assess LCLUC, quantifies ES change in response to LCLUC, and statistical analysis. The third and fourth sections give the results and discussion, respectively, and the fifth section concludes and provides some future recommendations. 


\section{Materials and methods}

\section{Study area}

The RVLR of Ethiopia ( $38^{\circ} 11^{\prime}$ to $39^{\circ} 9^{\prime} \mathrm{E}$ and $6^{\circ} 55^{\prime}$ to $\left.8^{\circ} 29^{\prime} \mathrm{N}\right)$ (Fig. 1), is located in the Eastern part of the Great African Rift system, with an altitude ranging from $1,384 \mathrm{~m}$ at the valley floor to more than $3,040 \mathrm{~m}$ asl at the escarpment (Fig. 1). The region where the study conducted includes eight administrative districts and two town districts with a total area of about 0.81 million ha (Table 6 ) and a projected population for 2017 of 2.1 million (CSA, 2013). The national GDP per capita was about USD233.82 in 1986 and USD706.76 in 2016 (WorldBank, 2019). The study region is characterised by rift valley lakes, namely Ziway, Langano, Shalla, Abiyata, Hawasa Lakes and Koka. Lake Ziway is one of the centres for agricultural development in the country (Hengsdijk and Jansen, 2006); Lake Abyata and Lake Shalla are important nature reserves, integrating the Abyata-Shala Lakes National Park, primarily established for aquatic bird protection (de Francisco et al., 2008; Hengsdijk and Jansen, 2006), which is currently heavily invaded by human and cattle populations (Scholten, 2007). Lake Hawasa, situated at the high elevation in the central main Ethiopian Rift Valley, is one of the essential bird sanctuaries in the country and is significant source of tourism income (Wondrade et al., 2014; Ayenew and Gebreegziabher, 2006). Lake Koka (artificial) is the second oldest hydro-power dam in the country. It provides multiple services besides hydropower (Gebretsadik, 2016). The study area also covers another sanctuary established for protecting Swayne's hartebeest (Alcelaphus buselaphus swaynei) which is called Sinkele sanctuary, located in the southwest of the study area (Nishizaki, 2004). The climate is arid to semi-arid (Scholten, 2007), but varies markedly with altitude (Jansen et al., 2007), with an annual precipitation of about $600 \mathrm{~mm}$. About $70 \%$ of the rainfall is received from July to September.

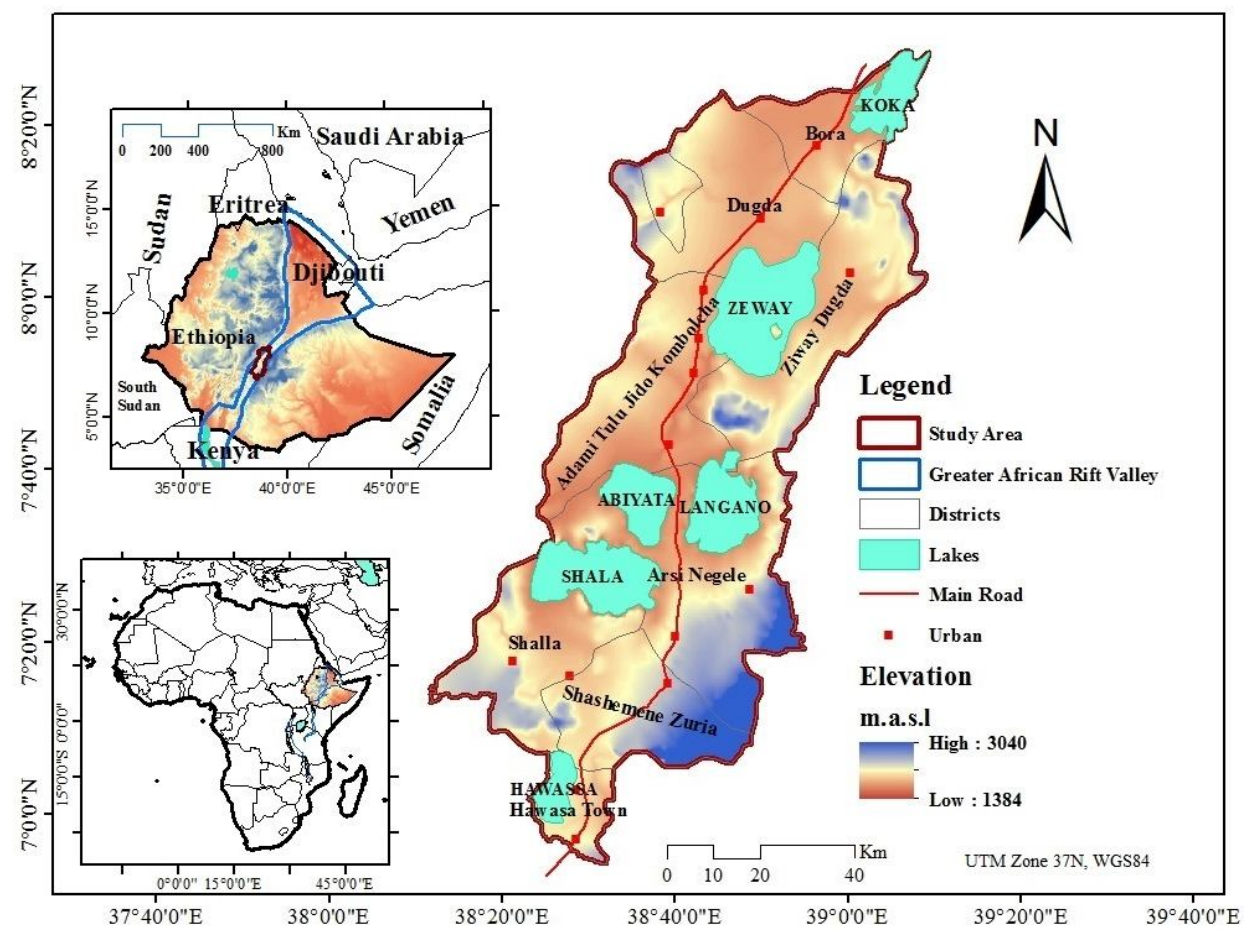

Figure 1. Location of the study area: RVLR of Ethiopia, East African Rift system 


\section{Methods}

The methods followed were an analysis of remotely-sensed data to detect LCLUCs and to estimate economic values for ES in response to LCLUC using a modified ES value coefficient.

\section{Data processing and LCLUC detection}

The LCLU datasets were derived from multi-spectral Landsat imageries (Landsat-5 Thematic Mapper (TM) 1986, Landsat-7 Enhanced Thematic Mapper Plus (ETM+) 2000, and Landsat-8 Operational Land Imager (OLI) 2018 with 30 m resolution (USGS, 2018). Two Landsat imageries were needed to get complete coverage of the study region. Therefore, a total of six imageries were acquired free of charge from the USGS (United States Geological Survey) Center for Earth Resources Observation and Science (EROS). Detailed characteristics of the remote sensing data (i.e. Landsat imageries) are tabulated in Table 1.

Table 1. Description of remote sensing data used in the study

\begin{tabular}{|c|c|c|c|c|c|}
\hline Year & Sensors & Path and row & Resolution & Date of acquisition & Source \\
\hline 1986 & $\begin{array}{l}\text { Landsat-5 Thematic } \\
\text { Mapper (TM) }\end{array}$ & $\begin{array}{l}168 / 054 \\
168 / 055\end{array}$ & $30 \mathrm{~m}$ & 21 Jan, 1986 & USGS, 2018 \\
\hline 2000 & $\begin{array}{l}\text { Landsat-7 Enhanced } \\
\text { Thematic Mapper Plus } \\
(\text { ETM }+)\end{array}$ & $\begin{array}{l}168 / 054 \\
168 / 055\end{array}$ & $30 \mathrm{~m}$ & 29 Feb, 2000 & USGS, 2018 \\
\hline 2018 & $\begin{array}{l}\text { Landsat-8 Operational } \\
\text { Land Imager (OLI) }\end{array}$ & $\begin{array}{l}168 / 054 \\
168 / 055\end{array}$ & $30 \mathrm{~m}$ & 13 Jan, 2018 & USGS, 2018 \\
\hline
\end{tabular}

Each of the acquired imageries was clear and nearly free of clouds. Imageries were pre-processed in ERDAS Imagine 2015 software (Hexagon Geospatial, Alabama, USA) for geometric corrections, geo-referencing, mosaicking and sub-setting of the images (Lin et al., 2018; Gashaw et al., 2017; Mosammam et al., 2017; Gebrehiwot et al., 2014; Schulz et al., 2010; Teferi et al., 2010). All of Landsat imageries were geo-rectified to UTM/WGS84, zone $37 \mathrm{~N}$ coordinates using 1:250,000 topographic maps and $20 \mathrm{GPS}$ (global positioning system) points gathered during field observation using Garmin eTrex handheld instrument. Each of the pre-processed imageries was classified using a hybrid classification method that integrates both the supervised and unsupervised classification techniques (Gashaw et al., 2017; Gebrehiwot et al., 2014; Teferi et al., 2010). The unsupervised techniques utilizing Iterative Self-Organizing Data Analysis (ISODATA) grouping (Boakye et al., 2008) were employed as a starting point for collecting GPS points as ground truth points. Using signature editors (spectral signatures) of the unsupervised categories, a pixel-based supervised classification technique with the Maximum Likelihood algorithm (MLC) (Gebrehiwot et al., 2014) was conducted using GPS points collected. The GPS points (i.e., 80 from each LCLU class) were gathered for classifying LCLU classes of the year 2018. A brief description of the identified LCLU classes in the RVLR of Ethiopia is given in Table 2. Reference data from topographic maps (scale: 1:50,000 and 1:250,000) obtained from the Ethiopia Mapping Agency, Google Earth, raw images, focus group discussions, and researchers' experience of the area were also used for the classification of the 1986 and 2000 
images. Moreover, geo-linking Google Earth with ERDAS Imagine 2015 software was employed for classification. ERDAS Imagine 2015 software was employed for classification purposes.

Table 2. A brief description of LCLU classes identified in the RVLR of Ethiopia

\begin{tabular}{|c|c|}
\hline LCLU classes & Brief descriptions \\
\hline Cropland & Land used for rain-fed and irrigated cropping (small plot to large scale) \\
\hline Bare land & Non-vegetated areas dominated by rock outcrops, eroded and degraded land \\
\hline Forest land & Land dominated by plantation and natural forest \\
\hline Grassland & Grass $\&$ herb cover with scattered trees and shrubs \\
\hline Marsh & $\begin{array}{c}\text { Includes: river beds, intermittent ponds and marshy areas with shallow water and } \\
\text { permanent reed vegetation }\end{array}$ \\
\hline Urban/built-up & $\begin{array}{l}\text { Land mainly towns dominated by permanent residential areas of varied patterns } \\
\text { and scale occupied by backyards, compounds, individual houses, and industries }\end{array}$ \\
\hline Water body & $\begin{array}{c}\text { open water, lakes (Abiyata, Shalla, Ziway, Langano, and Koka), ponds, rivers and } \\
\text { streams }\end{array}$ \\
\hline Woodland & Woody acacia dominated areas, and trees outside forest \\
\hline
\end{tabular}

Lastly, to confirm the quality and usability of each of the classified imageries, classification accuracy was computed from the error matrix. The error matrix compares the information obtained by sample LCLU sites with that provided by the classified image. It is also used to calculate the user's, producer's and overall accuracies (Congalton, 1991). About 85 random points were generated for each LCLU class using a stratified random sampling approach for better accuracy assessment (Congalton, 1991). The reference sample points for the 1986 and 2000 images were collected from the respective historical Google Earth images (i.e., January 1986 and February 2000). A similar technique was conducted by Gashaw et al. (2017).

Accuracy classification assessments were performed for classified imageries of 1986, 2000 and 2018. Accordingly, the results of imagery classification showed that the overall accuracies were higher than $80 \%$, and the Kappa coefficients were found to be higher than 0.77 (Table 3). This clarified that the results of image classification were satisfactory for further analysis.

Table 3. Accuracy assessment of the1986, 2000, and 2018 classified images

\begin{tabular}{c|c|c|c|c|c|c}
\hline \multirow{2}{*}{ LCLU class } & \multicolumn{6}{|c}{ Classification accuracy } \\
\cline { 2 - 7 } & \multicolumn{2}{|c}{$\mathbf{1 9 8 6}$} & \multicolumn{2}{c}{$\mathbf{2 0 0 0}$} & \multicolumn{2}{c}{$\mathbf{2 0 1 8}$} \\
\cline { 2 - 7 } & Producer's & User's & Producer's & User's & Producer's & User's \\
\hline Cropland & 81.48 & 81.48 & 81.82 & 90 & 77.27 & 85 \\
Bare Land & 84.62 & 88 & 85.42 & 80.39 & 85.42 & 80.39 \\
Urban/built-up & 87.1 & 72.97 & 86.96 & 80 & 89.19 & 89.19 \\
Forest land & 76.92 & 80 & 73.68 & 82.35 & 72.22 & 81.25 \\
Grassland & 67.86 & 86.36 & 86.67 & 96.3 & 86.36 & 95 \\
Marsh areas & 85.71 & 73.68 & 80.43 & 75.51 & 80.43 & 74 \\
Water body & 80 & 96 & 83.33 & 89.29 & 79.31 & 88.46 \\
Woodland & 85.29 & 85.29 & 84 & 95.45 & 80.77 & 95.45 \\
Overall accuracy (\%) & 80.05 & & 81.82 & & 80.37 & \\
Kappa statistics & 0.77 & & 0.77 & & 0.74 & \\
\hline
\end{tabular}


Finally, the classified images were exported to ArcGIS 10.2 software (Esri, California, USA) for further spatial analysis and ES value spatial distribution mapping. The percentage of dynamics of LCLUC were computed using the following equation:

$$
\Delta L-\frac{A_{\gamma-A_{1}}}{A_{1}} \times 100
$$

where $\Delta \mathrm{L}$ is the LCLUC proportion, and $\mathrm{A}_{2}$ and $\mathrm{A}_{1}$ are final and initial area cover of the LCLU classes.

\section{Estimation of ES values}

Many scholars have used a range of methods to estimate ES value since 1970 (Zhang et al., 2015). Costanza et al. (1997) categorised the global biosphere into sixteen types of ecosystem and seventeen types of service functions and estimated their ES value. Although Costanza's method is criticised for its uncertainties (Braat and de Groot, 2012; Kreuter et al., 2001), it served as the basis for further progress in the development and use of monetary valuation studies (Braat and de Groot, 2012). Referring to Costanza's parameter, Xie et al. (2003) provided the equivalent weighting factors of ES per hectare of terrestrial ecosystems and used these factors to adjust the value coefficient for the ecosystems of China. Although Xie et al.'s (2003) approach to quantifying ES value is also criticised for its uncertainties, it is still broadly applied for its feasibility, particularly in data-scarce areas (Lin et al., 2018). The ES value coefficient was also modified by Van der Ploeg and De Groot (2010) for 11 biomes based on Costanza et al.'s (1997) estimates, which are very general and could not represent the regional context.

Moreover, an additional estimation of global ecosystems was undertaken by de Groot et al. (2012) and Costanza et al. (2014). Their estimates were also criticised for overemphasising some ES (Tolessa et al., 2017a). Hence, referring to the existing dataset of TEEB, compiled by the international Ecosystem Service Partnership (ESPwww.es-partnership.org), as well as the ES value coefficients of Costanza et al. (1997), and dataset from peer-reviewed included in (de Groot et al., 2012), other related research and expert knowledge of the study landscape conditions, Kindu et al. (2016) has modified the ES value coefficients for nine biomes for the Ethiopian case. A summary of LCLU categories and corresponding ES coefficients is provided in Table 4. We associated the eight LCLU classes in the RVLR of Ethiopia (Table 5) with the biomes identified by Kindu et al. (2016), and the closest equivalent biome was used as a proxy. Cropland was used as a substitute for cropland, grass/rangelands for grasslands, tropical forest for forest land and woodland, lakes/rivers for a water body and marsh areas, desert for bare land, and urban for urban/built-up.

In this study, we rely upon a more conservative ES coefficient using the benefit transfer approach, which provides a means to estimate values (both the market and the non-market components) of various ES by transferring information of the existing valuation research from a similar location (Costanza et al., 1997; Kubiszewski et al., 2017). It is the approach most often used to estimate the economic value of ES when time, funding, information accessibility or other difficulties prevent the usage of primary studies (Kreuter et al., 2001; Rolfe et al., 2015; Temesgen et al., 2018; Wilson and Hoehn, 2006). This approach has been used in numerous studies for instance, (Costanza et al., 1997; Kramer et al., 1997; Kubiszewski et al., 2013; Liu et al., 2010; 
Temesgen et al., 2018; Torras, 2000) to quantify the worth of ES. Although, there are some weaknesses to this approach such as the context sensitivity of value estimates the accuracy will noticeably improve as the extent, richness, and detail of the information increases (Troy and Wilson, 2006; Wilson and Hoehn, 2006).

Table 4. Details of modified annual value coefficient for ESs of individual LCLU classes (Kindu et al., 2016)

\begin{tabular}{c|c|c|c|c|c|c|c|c}
\hline \multirow{2}{*}{ ESs } & \multicolumn{7}{c}{ LCLU classes /biome (USD ha $\mathbf{y r}^{-\mathbf{1}}$ ) } \\
\cline { 2 - 9 } & Cropland & $\begin{array}{c}\text { Bare } \\
\text { Land }\end{array}$ & $\begin{array}{c}\text { Urban/ } \\
\text { built-up }\end{array}$ & $\begin{array}{c}\text { Forest } \\
\text { land }\end{array}$ & Grassland & $\begin{array}{c}\text { Marsh } \\
\text { areas }\end{array}$ & $\begin{array}{c}\text { Water } \\
\text { body }\end{array}$ & Woodland \\
\hline Water supply & 0 & 0 & 0 & 8 & 0 & 2117 & 2117 & 8 \\
Food production & 187.56 & 0 & 0 & 32 & 117.45 & 41 & 41 & 32 \\
Raw material & 0 & 0 & 0 & 51.24 & 0 & 0 & 0 & 51.24 \\
Genetic resources & 0 & 0 & 0 & 41 & 0 & 0 & 0 & 41 \\
Water regulation & 0 & 0 & 0 & 6 & 3 & 5445 & 5445 & 6 \\
Water treatment & 0 & 0 & 0 & 136 & 87 & 431.5 & 431.5 & 136 \\
Erosion control & 0 & 0 & 0 & 245 & 29 & 0 & 0 & 245 \\
Climate regulation & 0 & 0 & 0 & 223 & 0 & 0 & 0 & 223 \\
Biological control & 24 & 0 & 0 & 0 & 23 & 0 & 0 & 0 \\
Gas regulation & 0 & 0 & 0 & 13.68 & 7 & 0 & 0 & 13.68 \\
Disturbance regulation & 0 & 0 & 0 & 5 & 0 & 0 & 0 & 5 \\
Nutrient cycling & 0 & 0 & 0 & 184.4 & 0 & 0 & 0 & 184.4 \\
Pollination & 14 & 0 & 0 & 7.27 & 25 & 0 & 0 & 7.27 \\
Soil formation & 0 & 0 & 0 & 10 & 1 & 0 & 0 & 10 \\
Habitat/refugia & 0 & 0 & 0 & 17.3 & 0 & 0 & 0 & 17.3 \\
Recreation & 0 & 0 & 0 & 4.8 & 0.8 & 69 & 69 & 4.8 \\
Cultural & 0 & 0 & 0 & 2 & 0 & 0 & 0 & 2 \\
Total ES value & 225.56 & 0 & 0 & 986.69 & 293.25 & 8103.5 & 8103.5 & 986.69 \\
\hline
\end{tabular}

Table 5. Summary of LCLU categories and corresponding ES coefficients based on modified estimates (Kindu et al., 2016)

\begin{tabular}{c|c|c}
\hline LCLU Type & Equivalent biome & Modified value coefficient (USD ha \\
\hline Cropland & $\mathbf{~} \mathbf{~}^{-1}$ ) \\
Bare land & Cropland & 225.56 \\
Forest land & Desert & 0 \\
Grassland & Tropical Forest & 986.69 \\
Marsh areas & Grass/rangelands & 293.25 \\
Urban/built-up & Lakes/rivers & 8103.5 \\
Water body & Urban & 0 \\
Woodland & Lakes/rivers & 8103.5 \\
\hline
\end{tabular}

The ES value of each LCLU category, their corresponding service function and the total ES values for 1986, 2000 and 2018 were calculated using Equations 2, 4, and 3, respectively, as considered by (Temesgen et al., 2018; Hu et al., 2008; Li et al., 2007). The modified annual value coefficients that were used for this study are presented in Tables 4 and 5. 


$$
\begin{gathered}
\text { ES Vulue }_{K}=A_{K^{*}} \times V C_{k} \\
\text { ESVulue }=\Sigma\left(A_{K} \times V C_{k}\right) \\
\text { ESValue }_{f}=\Sigma\left(A_{K} \times V C_{k f}\right)
\end{gathered}
$$

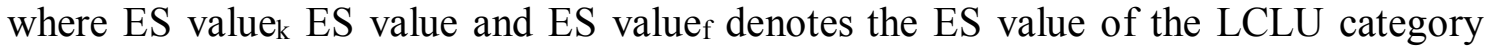
" $k$ ", the total ES value, and the value of ES function category " $\mathrm{f}$ ", respectively. $A_{k}$ is the area (ha) for LCLU category $\mathrm{k}$; $\mathrm{VC}_{\mathrm{kf}}$ is the value coefficient (USD ha ${ }^{-1} \mathrm{yr}^{-1}$ ) for LCLU category $\mathrm{k}$; and $\mathrm{VC}_{\mathrm{kf}}$ is the value coefficient (USD ha ${ }^{-1} \mathrm{yr}^{-1}$ ) for LCLU category $\mathrm{k}$ with ES function category " $\mathrm{f}$ ".

Estimation of the average ES values of the study area was undertaken using Equation 5, following the method employed in (Gashaw et al., 2018). The average ES value was calculated by dividing the total ES value by the area of the study region:

$$
\text { ESValue } a v-\frac{\text { ES Valug }}{\text { Areat }_{t}}
$$

where ES value $\mathrm{av}_{\mathrm{av}}$ is the average ES value of the study region (USD $\mathrm{ha}^{-1} \mathrm{yr}^{-1}$ ) during the specific year, ES value $t_{t}$ is the total ES value in that particular year, and Area is the area coverage of the study region.

\section{Statistical analysis}

To analyse the relationship between LCLUC, dynamics in ES value, and socioeconomic shift (i.e., GDP, population), one-way analysis of variance (ANOVA) was conducted. Moreover, to quantitatively scrutinise the relationship between LCLUC, and hence provide more information for this work, the analyses were carried out using IBM SPSS Statistics Version 20. By carefully examining whether the detected changes were significant or not, and the interaction effects of the variables, it was decided that nonlinear regression models were suitable and thus were adopted.

\section{Results}

\section{Land cover/land use change (1986-2018)}

The area coverage of LCLU classes (Table 6; Fig. 3) extracted as a result of the classification indicated that grassland, cropland, woodland, water bodies, forest land, bare land, urban/built-up and marsh areas were the dominant LCLU classes in the study period. The dominant LCLU classes that declined progressively over the study period were woodland, water bodies, grassland, forest land, and marsh areas. However, the highest decline was observed for woodland, which declined from $20.96 \%$ of the total area in 1986 to $16.75 \%$ in 2000 (i.e., declined by $20.09 \%$ ), and then declined to $11.52 \%$ in 2018 (i.e., declined by 31.24\%). The overall decrement of woodland was $45.05 \%$ between 1986 and 2018. Forest land decreased from 3.65\% in 1986 to $2.52 \%$ in 2018. Marsh areas also decreased from $2.28 \%$ in 1986 to $1.80 \%$ in 2018 . Grassland decreased from $26.77 \%$ in 1986 to $25.46 \%$ in 2018 . Water bodies decreased from $17.21 \%$ in 1986 to $15.72 \%$ in 2018 . During the last three decades (1986-2018), woodland, water bodies, forest land, marsh areas, and grassland all decreased, while cropland increased 
continually and remarkably from $25.89 \%$ of the total land in 1986 to $37.21 \%$ in 2018 . The aggregate area of bare land and urban/built-up, which constituted the smallest proportion of the study area (3.25\%) in 1986 speed up its expansion to $3.65 \%$ in 2000 and further to $5.78 \%$ in 2018 . On the other hand, a higher percent increment was indicated for urban/built-up by $34.79 \%$ from 1986 to 2000 and by $191.68 \%$, from 2000 to 2018 . The overall increment for urban/built-up was $293.14 \%$. The higher increment for urban/built-up does not mean a more extensive area covered by urban/built; instead, it refers to the proportional increment observed during the study period. Moreover, cropland and bare land increased by $43.72 \%$ and $50.10 \%$ from 1986 to 2018 , respectively.

Table 6. LCLU classes with their areas and changes (1986-2018)

\begin{tabular}{c|c|c|c|c|c|c|c|c|c}
\hline & \multicolumn{7}{|c|}{ LCLU area coverage } & \multicolumn{3}{c}{ LCLUC between periods $(\boldsymbol{\Delta} \mathbf{L})$} \\
\hline \multirow{2}{*}{ LCLU } & \multicolumn{2}{|c|}{$\mathbf{1 9 8 6}$} & \multicolumn{2}{|c|}{$\mathbf{2 0 0 0}$} & \multicolumn{2}{c}{$\mathbf{2 0 1 8}$} & $\mathbf{1 9 8 6}-\mathbf{2 0 0 0}$ & $\mathbf{2 0 0 0 - 2 0 1 8}$ & $\mathbf{1 9 8 6 - 2 0 1 8}$ \\
\cline { 2 - 10 } Classes & Area (ha) & \% & Area (ha) & \% & Area (ha) & \% & & \% & \% \\
\hline Cropland & 209659.05 & 25.89 & 252820.35 & 31.22 & 301319.55 & 37.21 & 20.59 & 19.18 & 43.72 \\
Bare land & 23320.98 & 2.88 & 25538.76 & 3.15 & 35005.41 & 4.32 & 9.51 & 37.07 & 50.10 \\
Urban/built-up & 2997.63 & 0.37 & 4040.37 & 0.50 & 11784.87 & 1.46 & 34.79 & 191.68 & 293.14 \\
Forest land & 29549.34 & 3.65 & 26504.37 & 3.27 & 20368.35 & 2.52 & -10.3 & -23.15 & -31.07 \\
Grassland & 216746.73 & 26.77 & 213019.29 & 26.31 & 206178.66 & 25.46 & -1.72 & -3.21 & -4.88 \\
Marsh areas & 18495.27 & 2.28 & 17054.91 & 2.11 & 14577.21 & 1.80 & -7.79 & -14.53 & -21.18 \\
Water body & 139326.84 & 17.21 & 135205.47 & 16.70 & 127309.95 & 15.72 & -2.96 & -5.84 & -8.62 \\
Woodland & 169704.81 & 20.96 & 135617.13 & 16.75 & 93256.65 & 11.52 & -20.09 & -31.24 & -45.05 \\
Total & 809800.65 & 100 & 809800.65 & 100 & 809800.65 & 100 & & & \\
\hline
\end{tabular}

\section{ES value dynamics (1986-2018)}

The value of ES for each LCLU class and the total ES value for 1986, 2000 and 2018 were estimated with the modified ES value coefficients (Table 5) and the area covered by each LCLU class in the RVLR of Ethiopia (Table 6). The finding indicated that the total ES value of the region was USD $1586.37 \times 10^{6}$ in 1986 , USD $1513.3 \times 10^{6}$ in 2000 and USD $1390.32 \times 10^{6}$ in 2018 (Tables 7 and 8). The total ES value showed a reduction of about USD $196.04 \times 10^{6}$ from 1986 to 2018 (Tables 7 and 8; Fig. 2 and 3), mainly due to the decreased areas of water bodies, woodland, marsh areas, and forest land. Even though the ES value of cropland increased, such increments were so small as to counterbalance the decreases in ES value of water bodies, woodland, marsh areas, and forest land.

Due to the highest value coefficient of water bodies (Table 4), they produce the highest ES value compared to the rest of the LCLU categories. Next to water bodies, woodland also produces a high ES value during 1986 because of its large area, which covered $20.96 \%$ of the studied region (Tables 6 and 7 ). The value coefficient of the marsh areas was also similar to that of the water body, and it produces the second highest ES value in 2000 and 2018 followed by woodland. The sub-total ES value of water body, woodland and marsh covered more than $89.32 \%$ of the total value (Tables 7 and 8). Even though the value coefficient of the forest land was similar to that of woodland, because forest land covered a small area in the study region, it contributed to low ES value. The ES value for cropland and grassland is also low owing to the low ES 
value coefficient (Table 7). Thus, the water body, woodland, and marsh LCLU categories were significant contributors to the ES value in the RVLR of Ethiopia in the last three decades (Fig. 3).
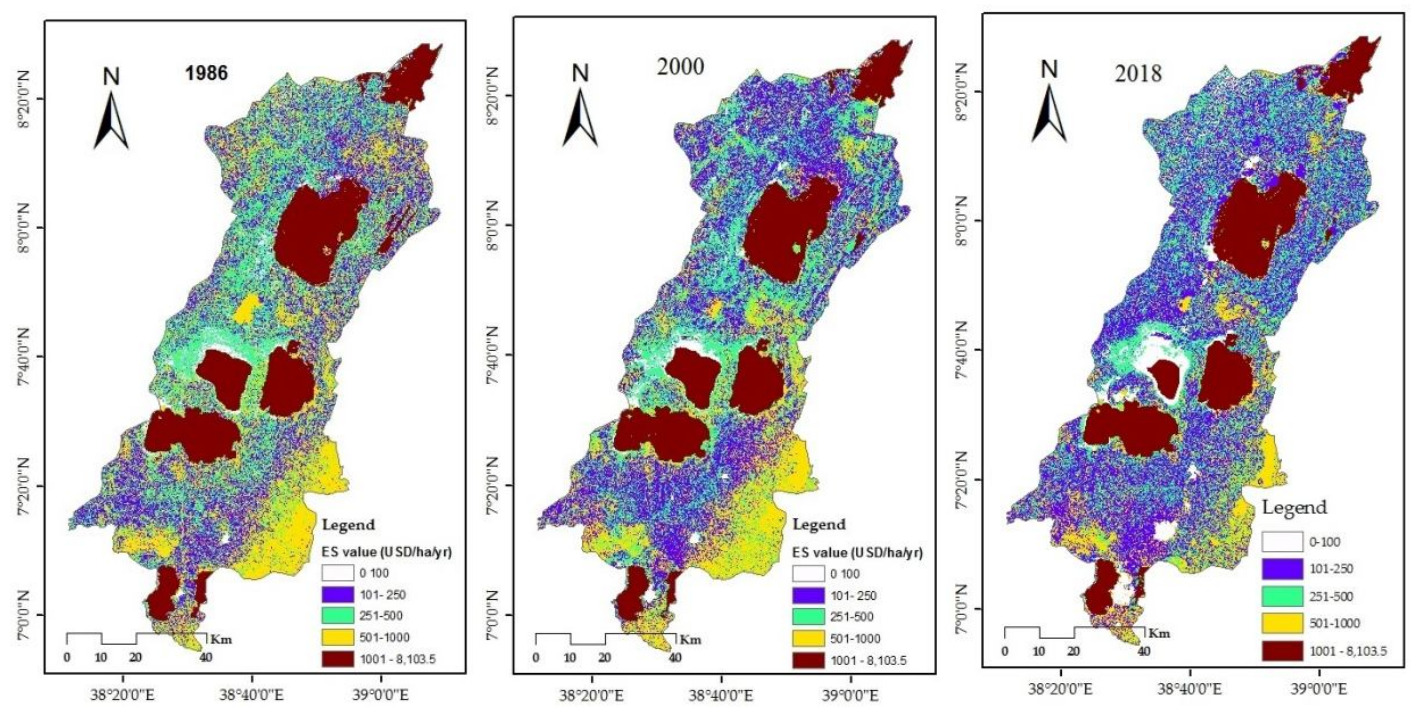

Figure 2. Spatial distribution of ES value in the RVLR of Ethiopia in 1986, 2000 and 2018 using modified estimates adopted from (Kindu et al., 2016)

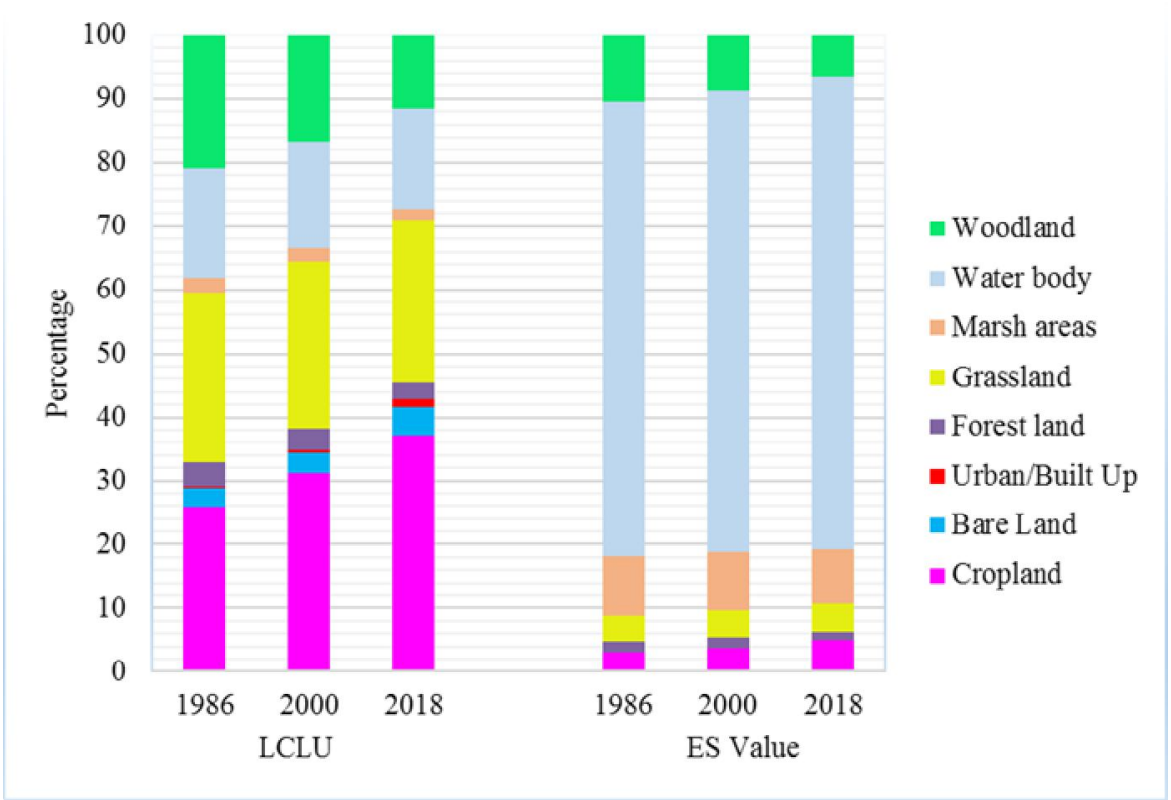

Figure 3. Proportions of LCLU (\%) and ES value (\%) for 1986, 2000 and 2018 in the RVLR of Ethiopia

Table 8 estimates an annual value of 17 ES. Concerning their contribution to the overall ES value, individual ES value functions were ranked from 1 to 17 (Table 8). The top six individual ES value functions were predominantly from the ES category of regulating (water regulation, water treatment, erosion control, climate regulation), 
provisioning (water supply and food production) for the study period (Table 8). Their combined contribution represented about USD $1488.11 \times 10^{6}, 1426.50 \times 10^{6}$, and $1319.12 \times 10^{6}$ in 1986,2000 and 2018 , respectively. The combined contribution of other ES functions of each ES category, i.e. supporting (nutrient cycling, pollination, habitat/refugia and soil formation), regulating (biological control, gas regulation and disturbance regulation), provisioning (genetic resources), and cultural services (recreation and cultural), were about USD98.25 $\times 10^{6}(6.19 \%)$, USD $86.8 \times 10^{6}(5.74 \%)$, USD $71.21 \times 10^{6}(5.12 \%)$ in 1986, 2000 and 2018, respectively. This order of contribution by ES categories remained unchanged over the three study periods.

Table 7. Total ES values estimated for each LCLU categories and changes from 1986 to 2018 in the study area

\begin{tabular}{c|c|c|c|c|c|c}
\hline \multirow{2}{*}{ LCLU Classes } & \multicolumn{7}{|c}{ ES value (USD million) } \\
\cline { 2 - 7 } & $\mathbf{1 9 8 6}$ & $\mathbf{2 0 0 0}$ & $\mathbf{2 0 1 8}$ & $\mathbf{1 9 8 6 - 2 0 0 0}$ & $\mathbf{2 0 0 0 - 2 0 1 8}$ & $\mathbf{1 9 8 6 - 2 0 1 8}$ \\
\hline Cropland & 47.29 & 57.03 & 67.97 & 9.74 & 10.94 & 20.67 \\
Bare Land & 0.00 & 0.00 & 0.00 & 0.00 & 0.00 & 0.00 \\
Urban/built-up & 0.00 & 0.00 & 0.00 & 0.00 & 0.00 & 0.00 \\
Forest land & 29.16 & 26.15 & 20.10 & -3.00 & -6.05 & -9.06 \\
Grassland & 63.56 & 62.47 & 60.46 & -1.09 & -2.01 & -3.10 \\
Marsh areas & 149.88 & 138.20 & 118.13 & -11.67 & -20.08 & -31.75 \\
Water body & 1129.04 & 1095.64 & 1031.66 & -33.40 & -63.98 & -97.38 \\
Woodland & 167.45 & 133.81 & 92.02 & -33.63 & -41.80 & -75.43 \\
\hline
\end{tabular}

In general, the total regulatory services contributed to more than two-thirds (about $67 \%$ ) of ES value, followed by provisioning (approximately 27\%), supporting (approximately $2.48 \%$ ), and cultural services (approximately $0.78 \%$ ) (Table 8). During the period 1986-2000, the ES values of supporting services declined more rapidly than any other ES $(-14.62 \%)$, followed by cultural $(-5.23 \%)$ and regulating services $(-5.10 \%)$.

The contribution of water regulation service to overall ES value was higher than $54 \%$ (the highest value), and cultural service was about $0.02 \%$ (the lowest value) (Table 8 ). The aggregate contributions of water regulation, water supply, water treatment, and food production, were more than $87 \%$ of the total ES value. During those three decades, the contribution of water regulation, water supply, and water treatment decreased, while the contribution of food production increased.

The change rate of each ecosystem functions was computed and the loss in ES value was observed in service functions of water regulation (USD $87.31 \times 10^{6}$ ), water supply (USD $34.42 \times 10^{6}$ ), erosion control (USD $21.29 \times 10^{6}$ ), water treatment (USD 19.44 $\left.\times 10^{6}\right)$, climate regulation (USD19.10 $\left.\times 10^{6}\right)$, nutrient cycling (USD15.79 $\left.\times 10^{6}\right)$, raw materials (USD $4.39 \times 10^{6}$ ), and genetic resources (USD $3.51 \times 10^{6}$ ), while the gains observed in ES values were in food production (USD $12.59 \times 10^{6}$ ), biological control (USD $1.96 \times 10^{6}$ ) and pollination (USD0.4 $\times 10^{6}$ ). The aggregate contribution of food production, biological control, and pollination was less than 9\%. The finding also indicated that dramatic expansion of cropland in the study landscape results in a consistent increment in the food production service function, though the increment was not drastic. 


$$
-7159-
$$

Table 8. Estimated value of ES function (ES value in USD million per year)

\begin{tabular}{|c|c|c|c|c|c|c|c|c|}
\hline \multirow{2}{*}{ ES } & \multicolumn{2}{|c|}{ ES value $_{1986}$} & \multicolumn{2}{|c|}{ ES value 2000} & \multicolumn{2}{|c|}{ ES value ${ }_{\text {t2018 }}$} & \multirow{2}{*}{$\begin{array}{l}\text { Overall } \\
\text { change }\end{array}$} & \multirow{2}{*}{ Rank } \\
\hline & & $\%$ & & $\%$ & & $\%$ & & \\
\hline \multicolumn{9}{|l|}{ Provisioning services } \\
\hline Water supply & 335.70 & 21.16 & 323.63 & 21.39 & 301.28 & 21.67 & -34.42 & 2 \\
\hline Food production & 77.63 & 4.89 & 83.87 & 5.54 & 90.18 & 6.49 & 12.56 & 4 \\
\hline Raw material & 10.21 & 0.64 & 8.31 & 0.55 & 5.82 & 0.42 & -4.39 & 11 \\
\hline Genetic resources & 8.17 & 0.51 & 6.65 & 0.44 & 4.66 & 0.34 & -3.51 & 12 \\
\hline \multicolumn{9}{|l|}{ Regulating services } \\
\hline Water regulation & 861.19 & 54.29 & 830.67 & 54.89 & 773.88 & 55.66 & -87.31 & 1 \\
\hline Water treatment & 114.06 & 7.19 & 106.28 & 7.02 & 94.61 & 6.81 & -19.44 & 3 \\
\hline Erosion control & 55.10 & 3.47 & 45.90 & 3.03 & 33.82 & 2.43 & -21.29 & 5 \\
\hline Climate regulation & 44.43 & 2.80 & 36.15 & 2.39 & 25.34 & 1.82 & -19.10 & 6 \\
\hline Biological control & 10.02 & 0.63 & 10.97 & 0.72 & 11.97 & 0.86 & 1.96 & 9 \\
\hline Gas regulation & 4.24 & 0.27 & 3.71 & 0.25 & 3.00 & 0.22 & -1.25 & 13 \\
\hline Disturbance regulation & 1.00 & 0.06 & 0.81 & 0.05 & 0.57 & 0.04 & -0.43 & 16 \\
\hline \multicolumn{9}{|l|}{ Supporting services } \\
\hline Nutrient cycling & 36.74 & 2.32 & 29.90 & 1.98 & 20.95 & 1.51 & -15.79 & 7 \\
\hline Pollination & 9.80 & 0.62 & 10.04 & 0.66 & 10.20 & 0.73 & 0.40 & 10 \\
\hline Soil formation & 2.21 & 0.14 & 1.83 & 0.12 & 1.34 & 0.10 & -0.87 & 15 \\
\hline Habitat/refugia & 3.45 & 0.22 & 2.80 & 0.19 & 1.97 & 0.14 & -1.48 & 14 \\
\hline \multicolumn{9}{|l|}{ Cultural services } \\
\hline Recreation & 12.02 & 0.76 & 11.45 & 0.76 & 10.50 & 0.76 & -1.52 & 8 \\
\hline Cultural & 0.40 & 0.03 & 0.32 & 0.02 & 0.23 & 0.02 & -0.17 & 17 \\
\hline Total ES value & 1586.37 & 100 & 1513.30 & 100 & 1390.32 & 100 & -196.04 & \\
\hline
\end{tabular}

\section{Variations of ES value in response to LCLUC and socioeconomic drivers}

Figure 4 indicates a negative non-linear relationship ES value per capita and GDP per capita. Regional GDP per capita in constant year-1986 prices increased by $69.5 \%$, from USD 233.82 in 1986 to USD 767.56 in 2018. At the same time, Regional ES value per capita reduced by 76.97\%, from USD 2706.86 in 1986 to USD 623.45 in 2018. Moreover, Figure 5 indicates a polynomial decline in the ratio of total ES value to total GDP from 1986 to 2018.

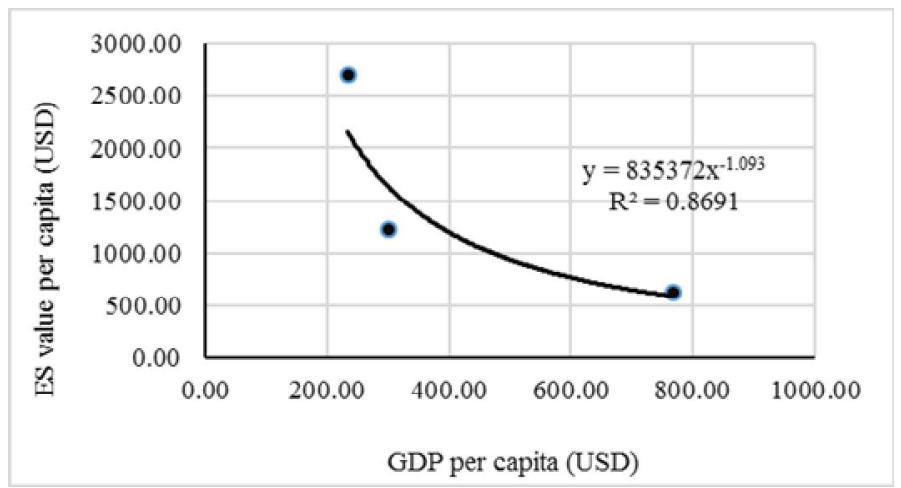

Figure 4. The relationship between ES value per capita and GDP per capita from 1986 to 2018 


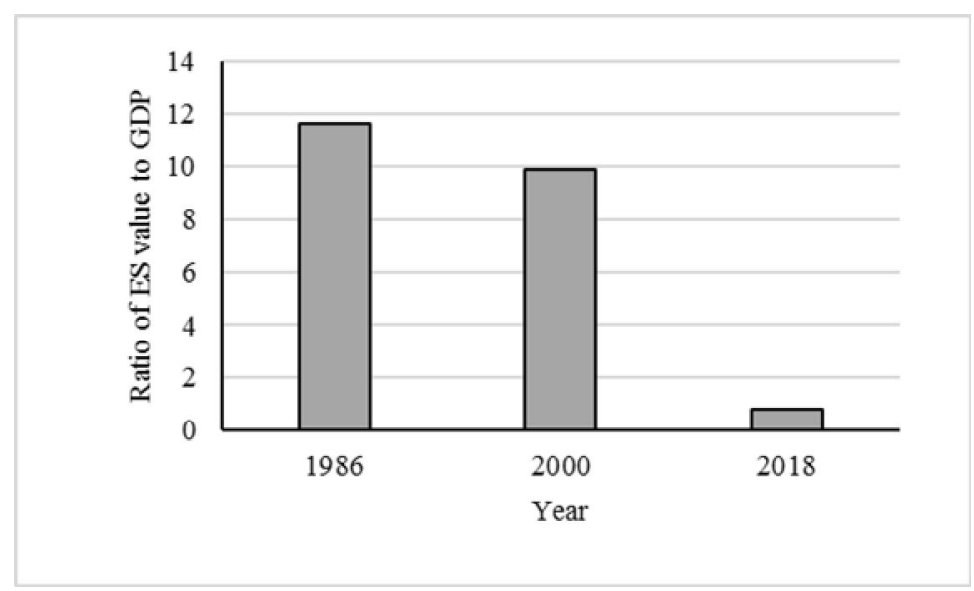

Figure 5. Changes in the ratio of total ES value to total GDP from 1986 to 2018

Additionally, both Figures 4 and 5 indicate that rapid economic growth had a significantly negative impact on regional ESs. Similar to Figure 2, Figures 6, 7 and 8 indicate the ongoing trend of reduction in ES value per capita and total ES value with significant demographic growth and continual expansion of built-up land, cropland and bare land.

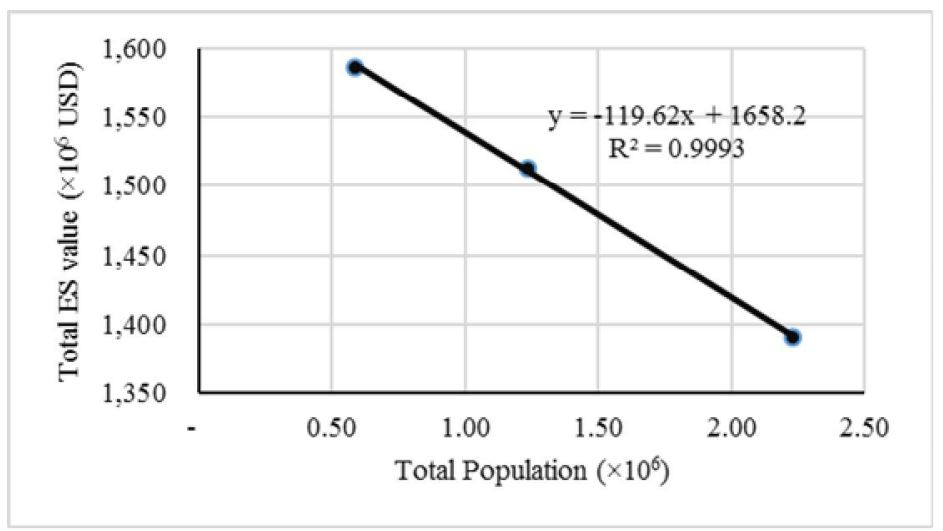

Figure 6. The relationship between total ES value and total regional population from 1986 to 2018

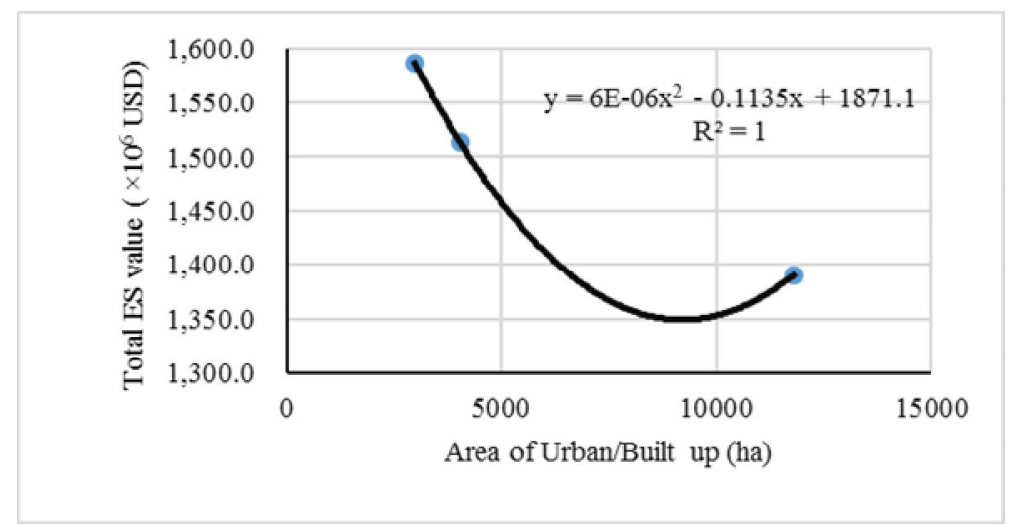

Figure 7. The relationship between ES value and area of urban/built-up from 1986 to 2018 


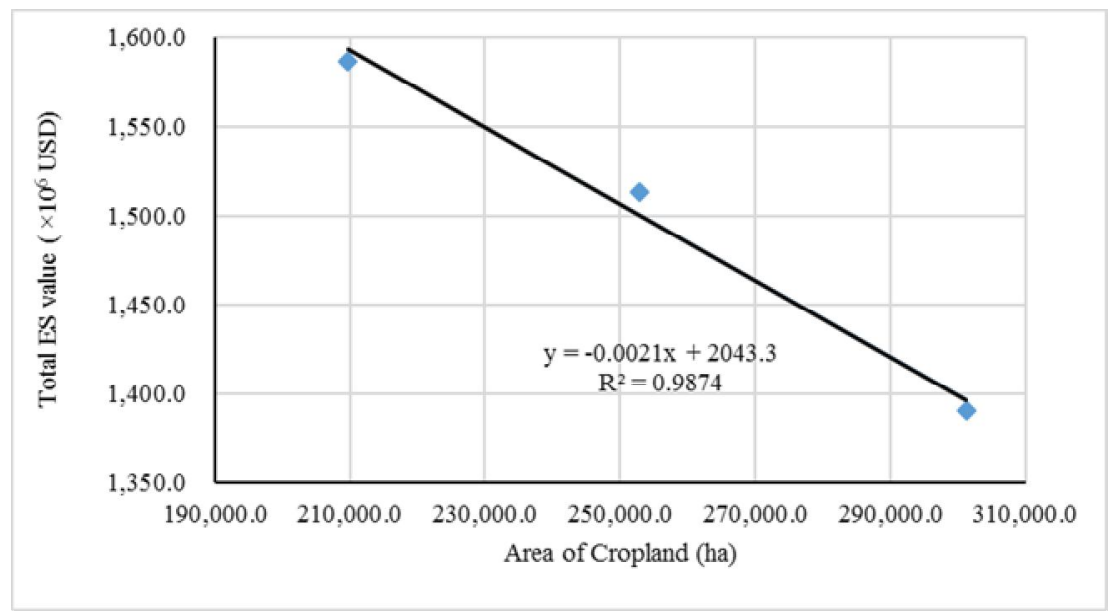

Figure 8. The relationship between total ES value and the area of cropland from 1986 to 2018

\section{Discussion}

\section{Dynamics of LCLU and ES value change}

In general, the area coverage of woodland, forest land, grassland, marsh areas, and water bodies consistently declined in varying proportions in the study period. The declines in these LCLU classes were mainly because of the conversion of the areas to cropland. The finding indicated that LCLUC is consistent with the results of previous research conducted in Ethiopia. For instance, the decline in woodland and the increase in cropland were also observed in Ziway-shalla basin (Bekele et al., 2018), Arsi-Negele district (Molla, 2015; Garedew et al., 2009), Munessa-Shashemene landscapes (Kindu et al., 2013), Central Rift Valley (Meshesha et al., 2012) in 1973-2010, 1973-2006, 1973-2006 and 1973-2012, respectively. Moreover, Kindu et al. (2013) and Meshesha et al. (2012) also reported a decrease in water bodies and forest land.

The loss of ES value in the RVLR of Ethiopia is predominantly due to the decreased areas of the water body, woodland, marsh areas, and forest land categories. According to Table 6 and Figure 3, there was a significant rise in the area of cropland over the other LCLU categories from $209,659.05$ ha in 1986 to $301,319.55$ ha in 2018. Remarkably, this increment exceeds the extent of land that changed from cropland to other LCLU types. The increment in the area of cropland increased the value of ES over the study period, but such increments were so small as to counterbalance the decreases in the total ES value in water bodies, woodland and forest land.

The trend of changes in ES value conforms with other studies in Ethiopia and elsewhere. For instance, in the Munessa-Shashemene landscapes, Kindu et al. (2016) reported a decline in ES value from 1973 to 2013. Gashaw et al. (2018) estimated a massive loss of ES value of about 21.7\% from 1986 to 2015 as a result of the altered forest, shrubland and grassland ecosystems in Andessa watershed, Ethiopia. Tolessa et al. (2017a) point out a cumulative decline of ES value of $40.7 \%$ from 1973 to 2015 in Chilimo Forest, Ethiopia, which was attributed to a reduction in forest cover. Another study by Tolessa et al. (2017b) also revealed an overall loss of $68 \%$ of ES value from 1973 to 2014 in Toke Kutaye district, Ethiopia, was mainly as a result of the loss of forest cover. A study mapping and quantifying ES in West Africa also reported an overall decline in ES value during 2000-2009 (Leh et al., 2013). Similarly, in Pingbian 
County, China (Li et al., 2007) revealed a 19.4\% decline of ES value during 1973-2004. San Antonio, Texas, (Kreuter et al., 2001) also reported a general decline of ES value of about USD $6 \times 10^{6}$ during 1976-1991. All these findings are in line with our finding that the dynamics of LCLU have resulted in a significant decline of ES value. On the other hand, an increase in ES values has been reported by studies in Ethiopia and elsewhere. For example, there were increases in the value of ES in Gedeo-Abay, Ethiopia (Temesgen et al., 2018), Ningxia, China (Wang et al., 2014), and Chengdu, China (Li et al., 2018) of 14.2\% during 1986-2015, 22.7\% during 2000-2010, and $75.46 \%$ during 2000-2015, respectively.

Specifically, the results of the study showed that the predominant types of LCLU by which the ES value in RVLR were water body, marsh areas, and woodland, which contributed over $89 \%$ of the total values. For water bodies, the ES value accounted for $74.2 \%$ of the total value in 2018 , which related to the high ES value coefficient in water bodies. According to Zhou et al. (2017), water bodies and wetlands were significant contributors to ES value, which covers more than $60 \%$ of the total, in Denqing, China during 1995-2015. The ES value of water bodies in the study region was high during the study period; however, its ES value was declining due to the degradation of the water environment, especially weak protection and rehabilitation of Feeder rivers, and water conservation in the study region. Bekele et al. (2018) noted the occurrence of severe lake water degradation in the region such as accelerated retreat of Lake Ziway and Lake Abiyata, drying/reduction of Rivers and Stream volumes (e.g., Bulbula River), huge water abstraction for irrigation (Raventós Vilalta, 2010; Legesse and Ayenew, 2006), and water pollution from the chemical intensified farming. The most apparent effect of water abstraction for trona or soda ash production during the last three decades, has been decline in the water level at Lake Abiyata (Legesse and Ayenew, 2006) and reduced about 50\% of the area between 1973 and 2006 (Hengsdijk et al., 2009), which could forms as terminal lake of the closed Central Rift valley basin (Getnet et al., 2014).

The projected dynamics by Jansen et al. (2007) and Raventós Vilalta (2010) indicated that Lake Abiyata and Lake Ziway would continue to lose more than $10 \%$ of their area coverage until 2034. Studies also projected that Lake Abiyata would dry up within the coming five decades (Seyoum et al., 2015; Temesgen et al., 2013; Jansen et al., 2007). In line with this, unless rehabilitation and restoration actions are taken, the adjacent Lake Ziway also faces a similar fate of drying shortly (Bekele et al., 2018; Jansen et al., 2007) since it is an open lake connected to Lake Abiyata through Bulbula River. The lowering in the discharge of the Feeder River and the declining of the water level of Ziway Lake are owing to the development of recently irrigated land (Scholten, 2007). According to Jansen et al. (2007), Lake Ziway has declined by about $0.5 \mathrm{~m}$ since 2002 that is equivalent to a loss of approximately $200 \times 10^{6}$ cubic meters of water. Similarly, Lake Cheleka whose area coverage was $11.3 \mathrm{~km}^{2}$ in 1973 , was gone entirely in the year 2011, changed into swamp and mud flats, while Lake Hawasa showed an increment from $91.9 \mathrm{~km}^{2}$ in 1973 to $95.2 \mathrm{~km}^{2}$ in 2011 , which is a rise of about $3.3 \mathrm{~km}^{2}$ between 1973 and 2011 (Wondrade et al., 2014). However, early research works showed a relatively broad area cover estimates inclusive of Lake Cheleka. For example, $150 \mathrm{~km}^{2}$ (Zanon, 1942 cited in Ayenew and Gebreegziabher, 2006). Moreover, a study by Bewketu (2010) revealed a decline in Lake Langano's water level. This, in turn, constitutes a significant threat to biodiversity loss, especially fish and bird species besides a significant loss to ES value at large. 
Therefore, protecting those LCLU classes that have high ES values is crucial for formulating a sustainable land use/cover policy, since this high ES value will help to maintain a sense of balance between ecosystem health and economic development in the future (Sawut et al., 2013). Similarly, Tianhong et al. (2010) suggested that land use planning should focus on LCLU classes with the highest ES value including water bodies, wetlands, and woodland.

The decline in the average ES value of the study region over the study period is because of the decline in water bodies, woodland, marsh areas and forest land and the expansion of cropland and urban/built-up areas. The calculated average ES value of the RVLR is higher than in other studies such as in Kashgar Region, (Mamat et al., 2018), Andassa watershed (Gashaw et al., 2018), Gedeo-Abaya landscape (Temesgen et al., 2018), Munessa-Shashemene landscape (Kindu et al., 2016), Chillimo Forest (Tolessa et al., 2017a), Toke Kutaye district (Tolessa et al., 2017b), and Menglun (Hu et al., 2008) (Table 9). The high average ES value of the RVLR could be attributed to the size of the water body, which cover more than $15 \%$ of the study region during the study period and high ES value coefficient for the water body. However, studies such as Wang et al. (2015) conducted in Nenjiang River Basin, Heilongjiang Province, Northeast China have shown higher average ES value as compared with our findings. If our study had employed the coefficient developed by Costanza et al. (1997) for a similar LCLU/biome (i.e. 8498 for water bodies, 2008 for woodland, 14,785 for marsh areas, 244 for grassland, 2008 for forest land and 92 for cropland) the overall ES value of the RVLR would have been USD1929.73 in 1986, USD1801.91 in 2000, and USD1603.59 in 2018. Subsequently, the average ES value of the study region would have slightly increased to USD2383 in 1986, USD2225 in 2000, and USD1980 in 2018. Moreover, considering the coefficients developed by Temesgen et al. (2018) for similar biomes (i.e. 3226.8 for water bodies, 897 for woodland, 2856.1 for marsh areas, 355.5 for grassland, 1093.2 for forest land and 169.2 for cropland) the overall ES value of the RVLR would have been USD 799.46 in 1986, USD754.12 in 2000, and USD682.64 in 2018. Subsequently, the average ES value of the study region would have dropped to USD987.2 in 1986, USD931.2 in 2000, and USD843.0 in 2018.

The reduction of most ES value functions during the study period is highly related to the decline in water bodies, marsh areas, woodland, and grassland. In line with this finding, a decline in the aquatic regions, grassland, and woodland between 2003 and 2013 period in Manas River Basin, China has caused a drop in the value of gas regulation, climate regulation and various types of ES value functions (Wang et al., 2017).

In this research, the consistent increase in food production, biological control, and pollination services over the study period is undoubtedly attributed to the expansion of cropland. The cropland category gained areas, which is negatively affecting the overall ES value for the study region. In the future, cropland area and the associated ES value will likely increase because of the increased need for food production to meet the growing population (WorldBank, 2019). These dynamics hurt the ES offered by other LCLU categories such as water bodies, woodland, marsh areas, grassland, and forest land. For example, the conversion of woodland and forest land to cropland is a negative factor affecting the provision of several ES, such as erosion control, which is a severe problem in the study region. It is evident that LCLU dynamics in Ethiopia has resulted in severe soil erosion and land deterioration, which in turn threaten food security and cause economic and social problems across the country (Zeleke and Hurni, 2001). On 
the other hand, loss of vegetation cover and deforestation induce erosion, and the deposition of nutrients and sediment accounts for the eutrophication in Lake Abiyata, which is already killing fish and other aquatic organisms inhabiting (Ayenew, 2007).

Table 9. The estimated average ES value of the selected studies and own estimation that was calculated using Equation 4 with the available data from the respective studies

\begin{tabular}{|c|c|c|c|c|c|}
\hline Study location & Area & Year & $\begin{array}{c}\text { ES value } \\
\left(\mathrm{USD} \times \mathbf{1 0}^{6}\right)\end{array}$ & $\begin{array}{c}\text { Average ES } \\
\text { value of the land } \\
\left(\mathrm{USD} \mathrm{ha}^{-1} \mathrm{yr}^{-1}\right. \\
\end{array}$ & Reference \\
\hline Kashgar Region, Northwest China & $11,350,200$ & $\begin{array}{l}1985 \\
2005 \\
2015\end{array}$ & $\begin{array}{l}10,845.3 \\
10,291.7 \\
10,127.3\end{array}$ & $\begin{array}{l}955.5 \\
906.7 \\
892.3\end{array}$ & $\begin{array}{l}\text { Mamat et al. } \\
\text { (2018) }\end{array}$ \\
\hline $\begin{array}{c}\text { Andassa watershed, Upper Blue Nile } \\
\text { basin, Ethiopia }\end{array}$ & 58,760 & $\begin{array}{l}1985 \\
2000 \\
2015\end{array}$ & $\begin{array}{c}26.83 \\
22.58 \\
21\end{array}$ & $\begin{array}{l}457 \\
384 \\
357\end{array}$ & $\begin{array}{l}\text { Gashaw et al. } \\
\text { (2018) }\end{array}$ \\
\hline $\begin{array}{c}\text { Gedeo_Abaya landscape, } \\
\text { Southeastern rift escarpment of } \\
\text { Ethiopia }\end{array}$ & $184,794.4$ & $\begin{array}{l}1986 \\
2000 \\
2015\end{array}$ & $\begin{array}{c}129 \\
145 \\
147.3 \\
\end{array}$ & $\begin{array}{l}698 \\
785 \\
797 \\
\end{array}$ & $\begin{array}{l}\text { Temesgen et } \\
\text { al. (2018) }\end{array}$ \\
\hline $\begin{array}{l}\text { Toke Kutaye district, West Shewa } \\
\text { zone of Oromia National Regional } \\
\text { State, Centeral highlands of Ethiopia }\end{array}$ & $72,697.2$ & $\begin{array}{l}1984 \\
2000 \\
2014\end{array}$ & $\begin{array}{l}33.93 \\
28.22 \\
16.71\end{array}$ & $\begin{array}{l}467 \\
388 \\
230\end{array}$ & $\begin{array}{l}\text { Tolessa et al. } \\
\qquad(2017 b)\end{array}$ \\
\hline $\begin{array}{l}\text { Munessa-Shashemene landscape, } \\
\text { Central highlands of Ethiopia }\end{array}$ & 103,675 & $\begin{array}{l}1986 \\
2000 \\
2012\end{array}$ & $\begin{array}{l}118.5 \\
114.8 \\
111.1\end{array}$ & $\begin{array}{l}1143 \\
1107 \\
1072\end{array}$ & $\begin{array}{l}\text { Kindu et al. } \\
\qquad(2016)\end{array}$ \\
\hline $\begin{array}{c}\text { Chillimo Forest, Dendi district of } \\
\text { Oromia National Regional State, } \\
\text { Ethiopia }\end{array}$ & 7687.26 & $\begin{array}{l}1986 \\
2001 \\
2015\end{array}$ & $\begin{array}{c}7.66 \\
6.4 \\
5.37\end{array}$ & $\begin{array}{l}996 \\
833 \\
699\end{array}$ & $\begin{array}{l}\text { Tolessa et al. } \\
\qquad(2017 \mathrm{a})\end{array}$ \\
\hline $\begin{array}{c}\text { Menglun, Xishuangbanna, Southwest } \\
\text { China }\end{array}$ & $33,488.34$ & $\begin{array}{l}1988 \\
2006\end{array}$ & $\begin{array}{c}41.2 \\
29.773\end{array}$ & $\begin{array}{c}1230 \\
889\end{array}$ & $\begin{array}{l}\text { Hu et al. } \\
(2008)\end{array}$ \\
\hline $\begin{array}{l}\text { Nenjiang River Basin, Heilongjiang } \\
\text { Province, Northeast China }\end{array}$ & $29,420,000$ & $\begin{array}{l}1980 \\
2005\end{array}$ & $\begin{array}{l}99,940 \\
97,510\end{array}$ & $\begin{array}{l}3397 \\
3314\end{array}$ & $\begin{array}{l}\text { Wang et al. } \\
\text { (2015) }\end{array}$ \\
\hline Rift Valley Lakes Region, Ethiopia & $809,800.65$ & $\begin{array}{l}1986 \\
2000 \\
2018\end{array}$ & $\begin{array}{c}1586.37 \\
1513.3 \\
1390.32\end{array}$ & $\begin{array}{l}1959 \\
1869 \\
1717\end{array}$ & Own data \\
\hline
\end{tabular}

Woodland and forest land provide services such as raw materials, food production, gas regulation, water regulation, water treatment, and recreation. However, this study confirmed the massive conversion of these LCLU categories to cropland during the study period. According to Arndt et al. (2011), the most common farming system in Ethiopia is small-scale subsistence rain-fed farming, which accounts for $90 \%$ of the country's agricultural output. Farming in the country was characterised with a low level of productivity due to a lack of production technologies, weak extension services, low use of improved seed, and minimal application of pesticides and fertilisers (Deressa, 2007). Consequently, to increase agricultural production, small farms expand their growing area by converting other LCLU categories to cropland. Similar to this finding, 
the increment in the intensity of cultivated land was attributed to the decline in the woodland and forest land categories between 1973 and 2006 in the Central Rift Valley, Ethiopia (Meshesha et al., 2012). A study by Kibret et al. (2016) also revealed that agricultural land is expanding to the maximum suitable size, even to the peripheral land, thus endangering biodiversity. Also, the conversion of marsh areas to cropland is a negative factor regarding the provision of several ES, such as water regulation, water supply, water treatment, and recreation services, which is a prevalent problem in the RVLR. Therefore, changing the widely employed traditional farming system through the improved farming technologies would play an important role in intensifying the productivity of the cropland thereby increasing agricultural production rather than converting other LCLUC classes to cropland.

\section{Limitation of the study}

The method of employing LCLUC in estimating ES value for the period 1986-2018 includes various sources of limitation. The primary constraint of this research is related to the accuracy of the LCLU classification. The LCLU classification of 1986, 2000, and 2018 was attained with an overall accuracy of $80.05 \%, 81.82 \%$ and $80.37 \%$, and kappa coefficient of $0.77,0.76$, and 0.74 (Table 3), respectively. Although the classification result meets the standard requirement (kappa coefficient higher than 0.70) (Monserud, 1990), there are still some limitations that are associated with the classification. There are also limitations from the adopted benefit transfer approach, such as considering all biomes/LCLU classes as a similar unit and using the same ES value coefficient derived from another site as an average unit value. This approach presumes the sameness of ESs values within the whole biomes/LCLU classes (Arowolo et al., 2018). Although there are drawbacks, this approach is often the only or the best option available for policy analysts and resource managers when time, information accessibility, or other difficulties prevent the usage of primary studies. Furthermore, funding limitations for gathering the primary data in developing countries such as Ethiopia often make benefit transfer is the sole feasible option.

Moreover, numerous studies used the coefficient of sensitivity approach to check the reliability of the ES value estimations, and mostly the value coefficients of ES value were corrected by $\pm 50 \%$, (e.g. Hu et al., 2008; Temesgen et al., 2018; Tolessa et al., 2017a; Yirsaw et al., 2017). Nevertheless, employing this approach to test the reliability of evaluation results is disapproved of since the value of the coefficient of sensitivity is often less than 1 even when the values of the coefficients of sensitivity were corrected by $\pm 25 \%$, which implies incorrectly robust coefficients (Aschonitis et al., 2016). Thus, this study did not conduct a coefficient of sensitivity analysis to check the validity of the estimation with another approach. Hence, another reliable approach that accounts the uncertainty needs to be considered. However, this study will contribute to the development of scientific literature on a similar topic to scrutinise how ES value is altering in response to the existing LCLUC.

Research of this kind is limited in many regions of Africa, which has resulted in a lack of information for decision making procedure about resource conservation and sustainable utilisation. It could also be used in data-short areas of developing regions with a similar landscape. Therefore, the findings of this study will offer regional-scale information to be added to global values for decision-making procedures. Besides the local level estimation, this study also emphasises the importance of regional-level and 
country-level ES value estimation based on expert knowledge of the region for better estimation of the LCLU/biome.

\section{Conclusions}

This study provides estimations of the ES value alteration in response to the dynamics of LCLU in the Rift Valley Lakes region of Ethiopia. The dynamics of LCLU over the past 33 years have resulted in a decline in the specific and overall ES value. Our estimation of the ES value alteration in response to LCLUC has indicated an overall reduction of approximately USD $5.77 \times 10^{6}$ per year, or a total loss of about $12.4 \%$ over the last 33 years. These changes are mostly associated with the decreased areas of the water body, woodland, marsh areas, forest land, and grassland categories. However, cropland has experienced a dramatic expansion by $43.72 \%$ during the study period. The estimation of lost ES value is about 9.5 times larger than the whole value of cropland in the study area. Water bodies, woodland and marsh areas were the three major contributors to the ES value in the RVLR of Ethiopia, contributing more than $89.32 \%$ of the overall ES value in 2018, indicating that these LCLU classes play an essential role in the ES of the study area.

LCLUC in the RVLR of Ethiopia affects the supply of ES, including water regulation, water supply, water treatment, and food production, erosion control, climate regulation, nutrient cycling, recreation, raw material, genetic resources, gas regulation, habitat/refugia, soil formation, disturbance regulation, and cultural service function. However, as a result of the dramatic expansion of cropland, the worth of food production, biological control, and pollination service function has invariably increased, though not drastically, over the study period. Except for these three ES functions, all other values have been decreasing continuously over the last three decades, indicating the deterioration of the fragile Rift Valley ecosystem.

In this research, the loss of ES value in RVLR was attributed to the dynamics of LCLU, which can impede the ability of the ecosystem to offer sustainable ES, possibly causing a long-term deterioration of the natural environment quality. In other words, these changes signify severe environmental repercussions for the fragile RVLR ecosystem. To enhance the continuous supply of ES, management should focus on LCLU classes with the highest ES values. Moreover, a nation-wide food security strategy of boosting crop production should work towards sustainable agricultural intensification rather than expanding cropland at the expense of the other LCLU classes. Hence, to improve the continuous supply of ES and economic development, an integrated approach to managing land and water resources needs to be considered. Furthermore, designing and operating a payment scheme for ES at the regional and local is also a potential remedy for ES loss. Moreover, quantitative assessment of ES value at local and regional scales should be considered as a conservation strategy to encourage resource conservation and utilisation.

Acknowledgements. The authors are pleased to acknowledge the financial support from the National Natural Sciences Foundation of China (Fund No. 41571176). The first author thanks Chinese Government Scholarship Council (CSC) for granting scholarship.

Conflict of interests. The authors declare no conflict of interests. 


\section{REFERENCES}

[1] Alarcon, G., Antônio dos Santos de Freitas, L., Oliveira da Fountoura, G., Ximenes de Macedo, C., Casarin Ribeiro, D. (2016): The challenges of implementing a legal framework for Payment for Ecosystem Services in Santa Catarina, Brazil. - Natureza \& conservaçao revista brasileira de conservaçao da natureza 14(2). DOI: 10.1016/j.ncon.2016.05.003.

[2] Arndt, C., Robinson, S., Willenbockel, D. (2011): Ethiopia's growth prospects in a changing climate: A stochastic general equilibrium approach. - Global Environmental Change 21(2): 701-710.

[3] Arowolo, A. O., Deng, X., Olatunji, O. A., Obayelu, A. E. (2018): Assessing changes in the value of ecosystem services in response to land-use/land-cover dynamics in Nigeria. Science of the Total Environment 636: 597-609.

[4] Aschonitis, V., Gaglio, M., Castaldelli, G., Fano, E. (2016): Criticism on elasticitysensitivity coefficient for assessing the robustness and sensitivity of ecosystem services values. - Ecosystem Services 20: 66-68.

[5] Ayenew, T. (2004): Environmental implications of changes in the levels of lakes in the Ethiopian Rift since 1970. - Regional Environmental Change 4(4): 192-204. DOI: 10.1007/s10113-004-0083-x.

[6] Ayenew, T. (2007): Water management problems in the Ethiopian rift: challenges for development. - Journal of African Earth Sciences 48(2-3): 222-236.

[7] Ayenew, T., Gebreegziabher, Y. (2006): Application of a spreadsheet hydrological model for computing the long-term water balance of Lake Awassa, Ethiopia. - Hydrological Sciences Journal 51(3): 418-431.

[8] Bartkowski, B. (2017): Are diverse ecosystems more valuable? Economic value of biodiversity as result of uncertainty and spatial interactions in ecosystem service provision. - Ecosystem Services 24: 50-57.

[9] Baveye, P., Baveye, J., Gowdy, J. (2013): Monetary valuation of ecosystem services: it matters to get the timeline right. - Ecological Economics 95: 231-235. DOI: 10.1016/j.ecolecon.2013.09.009.

[10] Bekele, B., Wu, W., Legesse, A., Temesgen, H., Yirsaw, E. (2018): Socio-environmental impacts of land use/cover change in Ethiopian central rift valley lakes region, East Africa. - Applied Ecology and Environmental Research 16(5): 6607-6632. DOI: 10.15666/aeer/1605_66076632.

[11] Bewketu, K. (2010): Hydrodynamics of selected Ethiopian Rift Lakes. - Unpublished MSc Thesis, Addis Ababa University, Ethiopia. http://etdaauedu et/dspace/bitstream/123456789/2767/1/Kassaye\% 20Bewketu pdf.

[12] Boakye, E., Odai, S., Adjei, K., Annor, F. (2008): Landsat images for assessment of the impact of land use and land cover changes on the Barekese catchment in Ghana. European Journal of Scientific Research 22(2): 269-278.

[13] Braat, L. C., de Groot, R. (2012): The ecosystem services agenda: bridging the worlds of natural science and economics, conservation and development, and public and private policy. - Ecosystem Services 1(1): 4-15.

[14] Cabral, P., Feger, C., Levrel, H., Chambolle, M., Basque, D. (2016): Assessing the impact of land-cover changes on ecosystem services: a first step toward integrative planning in Bordeaux, France. - Ecosystem Services 22: 318-327.

[15] Chang, Y., Hou, K., Li, X., Zhang, Y., Chen, P. (2018): Review of land use and land cover change research progress. - IOP Conference Series: Earth and Environmental Science 113(1): 012087.

[16] Chen, M., Lu, Y., Ling, L., Wan, Y., Luo, Z., Huang, H. (2015): Drivers of changes in ecosystem service values in Ganjiang upstream watershed. - Land Use Policy 47: 247252. 
[17] Congalton, R. G. (1991): A review of assessing the accuracy of classifications of remotely sensed data. - Remote Sensing of Environment 37(1): 35-46.

[18] Costanza, R., d'Arge, R., De Groot, R., Farber, S., Grasso, M., Hannon, B., Limburg, K., Naeem, S., O'neill, R. V., Paruelo, J. (1997): The value of the world's ecosystem services and natural capital. - Nature 387(6630): 253-260.

[19] Costanza, R., de Groot, R., Sutton, P., van der Ploeg, S., Anderson, S. J., Kubiszewski, I., Farber, S., Turner, R. K. (2014): Changes in the global value of ecosystem services. Global Environmental Change 26: 152-158.

[20] CSA (2013): Population Projection of Ethiopia for All Regions at Wereda Level from 2014-2017. - Central Statistical Agency, Ethiopia.

[21] Daily, G. C. (1997): Nature's Services: Societal Dependence on Natural Ecosystems. Islands Press, Washington, DC.

[22] de Bello, F., Lavorel, S., Díaz, S., Harrington, R., Cornelissen, J. H. C., Bardgett, R. D., Berg, M. P., Cipriotti, P., Feld, C. K., Hering, D., Martins da Silva, P., Potts, S. G., Sandin, L., Sousa, J. P., Storkey, J., Wardle, D. A., Harrison, P. A. (2010): Towards an assessment of multiple ecosystem processes and services via functional traits. Biodiversity and Conservation 19(10): 2873-2893. DOI: 10.1007/s10531-010-9850-9.

[23] de Francisco, J. C. R., Hellegers, I. P., Hengsdijk, H., Weikard, H. P. (2008): Preconditions for a Payment for Environmental Services establishment at Central Rift Valley, Ethiopia. - Environmental Economics and Natural Resources Group, Department of Environmental Sciences, Wageningen University.

[24] de Groot, R., Brander, L., van der Ploeg, S., Costanza, R., Bernard, F., Braat, L., Christie, M., Crossman, N., Ghermandi, A., Hein, L., Hussain, S., Kumar, P., McVittie, A., Portela, R., Rodriguez, L. C., ten Brink, P., van Beukering, P. (2012): Global estimates of the value of ecosystems and their services in monetary units. - Ecosystem Services 1(1): 50-61. DOI: https://doi.org/10.1016/j.ecoser.2012.07.005.

[25] Deressa, T. T. (2007): Measuring the economic impact of climate change on Ethiopian agriculture. - World Bank Policy Research Working Paper No. 4342.

[26] Egoh, B., Reyers, B., Rouget, M., Bode, M., Richardson, D. M. (2009): Spatial congruence between biodiversity and ecosystem services in South Africa. - Biological Conservation 142(3): 553-562. DOI: https://doi.org/10.1016/j.biocon.2008.11.009.

[27] Fedele, G., Locatelli, B., Djoudi, H., Colloff, M. J. (2018): Reducing risks by transforming landscapes: Cross-scale effects of land-use changes on ecosystem services. - PloS One 13(4): e0195895.

[28] Foley, J. A., DeFries, R., Asner, G. P., Barford, C., Bonan, G., Carpenter, S. R., Chapin, F. S., Coe, M. T., Daily, G. C., Gibbs, H. K. (2005): Global consequences of land use. Science 309(5734): 570-574.

[29] Garedew, E., Sandewall, M., Söderberg, U., Campbell, B. M. (2009): Land-use and landcover dynamics in the Central Rift Valley of Ethiopia. - Environmental Management 44(4): 683-694.

[30] Gashaw, T., Tulu, T., Argaw, M., Worqlul, A. W. (2017): Evaluation and prediction of land use/land cover changes in the Andassa watershed, Blue Nile Basin, Ethiopia. Environmental Systems Research 6(1): 17.

[31] Gashaw, T., Tulu, T., Argaw, M., Worqlul, A. W., Tolessa, T., Kindu, M. (2018): Estimating the impacts of land use/land cover changes on Ecosystem Service Values: The case of the Andassa watershed in the Upper Blue Nile basin of Ethiopia. - Ecosystem Services 31:219-228.

[32] Gebrehiwot, S. G., Bewket, W., Gärdenäs, A. I., Bishop, K. (2014): Forest cover change over four decades in the Blue Nile Basin, Ethiopia: comparison of three watersheds. Regional Environmental Change 14(1): 253-266.

[33] Gebretsadik, H. Y. (2016): Towards an optimal integrated reservoir system management for the Awash River Basin, Ethiopia. - Proceedings of the International Association of Hydrological Sciences 373: 215. 
[34] Getnet, M., Hengsdijk, H., van Ittersum, M. (2014): Disentangling the impacts of climate change, land use change and irrigation on the Central Rift Valley water system of Ethiopia. - Agricultural Water Management 137: 104-115.

[35] Hengsdijk, H., Jansen, H. (2006): Agricultural Development in the Central Ethiopian Rift Valley: A Desk-Study on Water-Related Issues and Knowledge to Support a Policy Dialogue. - Plant Research International B.V., Wageningen.

[36] Hengsdijk, H., Groot, A., van Driel, L., Jembere, K., van Uum, J., Boone, P. (2009): Towards a sustainable future of the western shoreline of Lake Ziway. - Participatory Land Use Plan Development Workshop, Ziway, December 1-4, 2008. Plant Research International.

[37] Hu, H., Liu, W., Cao, M. (2008): Impact of land use and land cover changes on ecosystem services in Menglun, Xishuangbanna, Southwest China. - Environmental Monitoring and Assessment 146(1): 147-156.

[38] Jacobs, S., Dendoncker, N., Martín-López, B., Barton, D. N., Gomez-Baggethun, E., Boeraeve, F., McGrath, F. L., Vierikko, K., Geneletti, D., Sevecke, K. J. (2016): A new valuation school: Integrating diverse values of nature in resource and land use decisions. - Ecosystem Services 22: 213-220.

[39] Jansen, H., Hengsdijk, H., Legesse, D., Ayenew, T., Hellegers, P., Spliethoff, P. (2007): Land and Water Resources Assessment in the Ethiopian Central Rift Valley. - Project: Ecosystems for Water, Food And Economic Development in the Ethiopian Central Rift Valley, Alterra.

[40] Kibret, K. S., Marohn, C., Cadisch, G. (2016): Assessment of land use and land cover change in South Central Ethiopia during four decades based on integrated analysis of multi-temporal images and geospatial vector data. - Remote Sensing Applications: Society and Environment 3: 1-19.

[41] Kindu, M., Schneider, T., Teketay, D., Knoke, T. (2013): Land use/land cover change analysis using object-based classification approach in Munessa-Shashemene landscape of the Ethiopian highlands. - Remote Sensing 5(5): 2411-2435. DOI: doi.org/10.3390/rs5052411.

[42] Kindu, M., Schneider, T., Teketay, D., Knoke, T. (2016): Changes of ecosystem service values in response to land use/land cover dynamics in Munessa-Shashemene landscape of the Ethiopian highlands. - Science of the Total Environment 547: 137-147. DOI: https://doi.org/10.1016/j.scitotenv.2015.12.127.

[43] Kramer, R. A., Richter, D. D., Pattanayak, S., Sharma, N. P. (1997): Ecological and Economic Analysis of Watershed Protection in Eastern Madagascar. - Journal of $\begin{array}{llll}\text { Environmental } & \text { Management } & \text { 277-295. }\end{array}$ https://doi.org/10.1006/jema.1995.0085.

[44] Kreuter, U. P., Harris, H. G., Matlock, M. D., Lacey, R. E. (2001): Change in ecosystem service values in the San Antonio area, Texas. - Ecological Economics 39(3): 333-346. DOI: https://doi.org/10.1016/S0921-8009(01)00250-6.

[45] Kubiszewski, I., Costanza, R., Anderson, S., Sutton, P. (2017): The future value of ecosystem services: global scenarios and national implications. - Ecosystem Services 26: 289-301.

[46] Kubiszewski, I., Costanza, R., Dorji, L., Thoennes, P., Tshering, K. (2013): An initial estimate of the value of ecosystem services in Bhutan. - Ecosystem Services 3: e11-e21.

[47] Legesse, D., Ayenew, T. (2006): Effect of improper water and land resource utilization on the central Main Ethiopian Rift lakes. - Quaternary International 148(1): 8-18.

[48] Legesse, D., Vallet-Coulomb, C., Gasse, F. (2004): Analysis of the hydrological response of a tropical terminal lake, Lake Abiyata (Main Ethiopian Rift Valley) to changes in climate and human activities. - Hydrological Processes 18(3): 487-504. DOI: 10.1002/hyp.1334. 
[49] Leh, M. D., Matlock, M. D., Cummings, E. C., Nalley, L. L. (2013): Quantifying and mapping multiple ecosystem services change in West Africa. - Agriculture, Ecosystems \& Environment 165: 6-18. DOI: 10.1016/j.agee.2012.12.001.

[50] Li, R.-Q., Dong, M., Cui, J.-Y., Zhang, L.-L., Cui, Q.-G., He, W.-M. (2007): Quantification of the impact of land-use changes on ecosystem services: a case study in Pingbian County, China. - Environmental Monitoring and Assessment 128(1): 503-510. DOI: 10.1007/s10661-006-9344-0.

[51] Li, Y., Zhan, J., Liu, Y., Zhang, F., Zhang, M. (2018): Response of ecosystem services to land use and cover change: a case study in Chengdu City. - Resources, Conservation and Recycling 132: 291-300.

[52] Liang, J., Zhong, M., Zeng, G., Chen, G., Hua, S., Li, X., Yuan, Y., Wu, H., Gao, X. (2017): Risk management for optimal land use planning integrating ecosystem services values: A case study in Changsha, Middle China. - Science of the Total Environment 579: $1675-1682$.

[53] Lin, X., Xu, M., Cao, C., P Singh, R., Chen, W., Ju, H. (2018): Land-use/land-cover changes and their influence on the ecosystem in Chengdu city, China during the period of 1992-2018. - Sustainability 10(10): 3580.

[54] Liu, S., Costanza, R., Troy, A., D’Aagostino, J., Mates, W. (2010): Valuing New Jersey's ecosystem services and natural capital: a spatially explicit benefit transfer approach. Environmental Management 45(6): 1271-1285. DOI: 10.1007/s00267-010-9483-5.

[55] Locatelli, B., Lavorel, S., Sloan, S., Tappeiner, U., Geneletti, D. (2017): Characteristic trajectories of ecosystem services in mountains. - Frontiers in Ecology and the Environment 15(3): 150-159.

[56] Mamat, A., Halik, Ü., Rouzi, A. (2018): Variations of ecosystem service value in response to land-use change in the Kashgar Region, Northwest China. - Sustainability 10(1): 200.

[57] MEA (2005): Ecosystems and Human Well-Being. - Island Press, Washington DC.

[58] Meshesha, D. T., Tsunekawa, A., Tsubo, M. (2012): Continuing land degradation: causeeffect in Ethiopia's Central Rift Valley. - Land Degradation \& Development 23(2): 130143. DOI: $10.1002 / \mathrm{ldr} .1061$.

[59] Molla, M. B. (2015): Land use/land cover dynamics in the Central Rift Valley region of Ethiopia: case of Arsi Negele District. - African Journal of Agricultural Research 10(5): 434-449.

[60] Monserud, R. (1990): Methods for Comparing Global Vegetation Maps. - Report WP-9040. IIASA, Laxenburg.

[61] Mosammam, H. M., Nia, J. T., Khani, H., Teymouri, A., Kazemi, M. (2017): Monitoring land use change and measuring urban sprawl based on its spatial forms: the case of Qom city. - The Egyptian Journal of Remote Sensing and Space Science 20(1): 103-116.

[62] Mwampamba, T. H., Abrams, R. W., Awoyemi, S., Babalola, F. D., Borokini, T. I., Egoh, B., Rguibi Idrissi, H., Koussa, T., Nganje, M., O'Leary, J. (2016): The implications of globalization for conservation in Africa. - African Journal of Ecology 54(2): 133-135.

[63] Nelson, E., Mendoza, G., Regetz, J., Polasky, S., Tallis, H., Cameron, D., Chan, K., Daily, G. C., Goldstein, J., Kareiva, P. M. (2009): Modeling multiple ecosystem services, biodiversity conservation, commodity production, and tradeoffs at landscape scales. Frontiers in Ecology and the Environment 7(1): 4-11.

[64] Niquisse, S., Cabral, P. (2018): Assessment of changes in ecosystem service monetary values in Mozambique. - Environmental Development 25: 12-22.

[65] Nishizaki, N. (2004): Resisting imposed wildlife conservation: Arssi Oromo and the Senkelle Swayne's Hartebeest sanctuary, Ethiopia. - African Study Monographs 25(2): 61-77.

[66] Polasky, S., Nelson, E., Pennington, D., Johnson, K. A. (2011): The impact of land-use change on ecosystem services, biodiversity and returns to landowners: a case study in the state of Minnesota. - Environmental and Resource Economics 48(2): 219-242. 
[67] Raventós Vilalta, E. (2010): Water resources management in the Central Rift Valley in Ethiopia. - MSc Thesis. Universitat Politecnica Catalunya, Spain.

[68] Reid, R. S., Kruska, R. L., Muthui, N., Taye, A., Wotton, S., Wilson, C. J., Mulatu, W. (2000): Land-use and land-cover dynamics in response to changes in climatic, biological and socio-political forces: the case of southwestern Ethiopia. - Landscape Ecology 15(4): 339-355.

[69] Rodríguez, J. P., Beard Jr, T. D., Bennett, E. M., Cumming, G. S., Cork, S. J., Agard, J., Dobson, A. P., Peterson, G. D. (2006): Trade-offs across space, time, and ecosystem services. - Ecology and Society 11(1).

[70] Rolfe, J., Johnston, R. J., Rosenberger, R. S., Brouwer, R. (2015): Introduction: Benefit Transfer of Environmental and Resource Values. - In: Johnston, R. J., Rolfe, J., Rosenberger, R. S., Brouwer, R. (eds.) Benefit Transfer of Environmental and Resource Values: A Guide for Researchers and Practitioners. Springer Netherlands, Dordrecht, pp. 3-17. DOI: $10.1007 / 978-94-017-9930-01$.

[71] Satz, D., Gould, R. K., Chan, K. M., Guerry, A., Norton, B., Satterfield, T., Halpern, B. S., Levine, J., Woodside, U., Hannahs, N. (2013): The challenges of incorporating cultural ecosystem services into environmental assessment. - Ambio 42(6): 675-684.

[72] Sawut, M., Eziz, M., Tiyip, T. (2013): The effects of land-use change on ecosystem service value of desert oasis: a case study in Ugan-Kuqa River Delta Oasis, China. Canadian Journal of Soil Science 93(1): 99-108.

[73] Schirpke, U., Kohler, M., Leitinger, G., Fontana, V., Tasser, E., Tappeiner, U. (2017): Future impacts of changing land-use and climate on ecosystem services of mountain grassland and their resilience. - Ecosystem Services 26: 79-94.

[74] Scholten, W. (2007): Agricultural development and water use in the Central Rift Valley of Ethiopia: a rapid appraisal. - Internship Report, University of Twente, The Netherlands.

[75] Schröter, D., Cramer, W., Leemans, R., Prentice, I. C., Araújo, M. B., Arnell, N. W., Bondeau, A., Bugmann, H., Carter, T. R., Gracia, C. A. (2005): Ecosystem service supply and vulnerability to global change in Europe. - Science 310(5752): 1333-1337.

[76] Schulz, J. J., Cayuela, L., Echeverria, C., Salas, J., Rey Benayas, J. M. (2010): Monitoring land cover change of the dryland forest landscape of Central Chile (19752008). - Applied Geography 30(3): 436-447. DOI: https://doi.org/10.1016/j.apgeog.2009.12.003.

[77] Seppelt, R., Dormann, C. F., Eppink, F. V., Lautenbach, S., Schmidt, S. (2011): A quantitative review of ecosystem service studies: approaches, shortcomings and the road ahead. - Journal of applied Ecology 48(3): 630-636. DOI: 10.1111/j.13652664.2010.01952.x.

[78] Seyoum, W. M., Milewski, A. M., Durham, M. C. (2015): Understanding the relative impacts of natural processes and human activities on the hydrology of the Central Rift Valley lakes, East Africa. - Hydrological processes 29(19): 4312-4324.

[79] Song, W., Deng, X. (2017): Land-use/land-cover change and ecosystem service provision in China. - Science of the Total Environment 576: 705-719.

[80] Sutton, P. C., Anderson, S. J., Costanza, R., Kubiszewski, I. (2016): The ecological economics of land degradation: Impacts on ecosystem service values. - Ecological Economics 129: 182-192.

[81] Tadesse, G., Zavaleta, E., Shennan, C., Fitzsimmons, M. (2014): Local ecosystem service use and assessment vary with socio-ecological conditions: a case of native coffee-forests in southwestern Ethiopia. - Human Ecology 42(6): 873-883. DOI: 10.1007/s10745-0149704-2.

[82] Teferi, E., Uhlenbrook, S., Bewket, W., Wenninger, J., Simane, B. (2010): The use of remote sensing to quantify wetland loss in the Choke Mountain range, Upper Blue Nile basin, Ethiopia. - Hydrology and Earth System Sciences 14(12): 2415-2428. 
[83] Temesgen, H., Nyssen, J., Zenebe, A., Haregeweyn, N., Kindu, M., Lemenih, M., Haile, M. (2013): Ecological succession and land use changes in a lake retreat area (Main Ethiopian Rift Valley). - Journal of Arid Environments 91(4): 53-60.

[84] Temesgen, H., Wu, W., Shi, X., Yirsaw, E., Bekele, B., Kindu, M. (2018): Variation in ecosystem service values in an agroforestry dominated landscape in Ethiopia: implications for land use and conservation policy. - Sustainability 10(4): 1126.

[85] Tianhong, L., Wenkai, L., Zhenghan, Q. (2010): Variations in ecosystem service value in response to land use changes in Shenzhen. - Ecological Economics 69(7): 1427-1435.

[86] Tolessa, T., Senbeta, F., Abebe, T. (2017a): The impact of land use/land cover change on ecosystem services in the central highlands of Ethiopia. - Ecosystem Services 26(2): 111123. DOI: $10.1080 / 14728028.2016 .1221780$.

[87] Tolessa, T., Senbeta, F., Abebe, T. (2017b): Land use/land cover analysis and ecosystem services valuation in the central highlands of Ethiopia. - Forests, Trees and Livelihoods 26(2): 111-123.

[88] Torras, M. (2000): The total economic value of Amazonian deforestation, 1978-1993. Ecological Economics 33(2): 283-297.

[89] Troy, A., Wilson, M. A. (2006): Mapping ecosystem services: practical challenges and opportunities in linking GIS and value transfer. - Ecological Economics 60(2): 435-449. DOI: https://doi.org/10.1016/j.ecolecon.2006.04.007.

[90] Tsegaye, D., Moe, S. R., Vedeld, P., Aynekulu, E. (2010): Land-use/cover dynamics in Northern Afar rangelands, Ethiopia. - Agriculture, Ecosystems \& Environment 139(1-2): 174-180.

[91] USGS (2018): Earth Explorer. - http://earthexplorer.usgs.gov/ (accessed 26.03.18).

[92] Van der Ploeg, S., De Groot, R. (2010): The TEEB Valuation Database-a Searchable Database of 1310 Estimates of Monetary Values of Ecosystem Services. - Foundation for Sustainable Development, Wageningen, The Netherlands.

[93] Vigl, L. E., Schirpke, U., Tasser, E., Tappeiner, U. (2016): Linking long-term landscape dynamics to the multiple interactions among ecosystem services in the European Alps. Landscape Ecology 31(9): 1903-1918.

[94] Wang, X., Dong, X., Liu, H., Wei, H., Fan, W., Lu, N., Xu, Z., Ren, J., Xing, K. (2017): Linking land use change, ecosystem services and human well-being: a case study of the Manas River Basin of Xinjiang, China. - Ecosystem Services 27: 113-123.

[95] Wang, Y., Gao, J., Wang, J., Qiu, J. (2014): Value assessment of ecosystem services in nature reserves in Ningxia, China: A response to ecological restoration. - PloS One 9(2): e89174.

[96] Wang, Z., Wang, Z., Zhang, B., Lu, C., Ren, C. (2015): Impact of land use/land cover changes on ecosystem services in the Nenjiang River Basin, Northeast China. Ecological Processes 4(1): 11. DOI: 10.1186/s13717-015-0036-y.

[97] Wilson, M. A., Hoehn, J. P. (2006): Valuing environmental goods and services using benefit transfer: The state-of-the art and science. - Ecological Economics 60(2): 335-342. DOI: https://doi.org/10.1016/j.ecolecon.2006.08.015.

[98] Wondrade, N., Dick, Ø. B., Tveite, H. (2014): GIS based mapping of land cover changes utilizing multi-temporal remotely sensed image data in Lake Hawassa Watershed, Ethiopia. - Environmental Monitoring and Assessment 186(3): 1765-1780.

[99] WorldBank (2019): https://data.worldbank.org/country/ethiopia. - WorldBank, Washington, DC.

[100] Xie, G.-D., Lu, C.-X., Leng, Y.-F., Zheng, D., Li, S. (2003): Ecological assets valuation of the Tibetan Plateau. - Journal of Natural Resources 18(2): 189-196. DOI: $10.1002 / 1 \mathrm{dr} .2575$.

[101] Xu, D., Ding, X. (2018): Assessing the impact of desertification dynamics on regional ecosystem service value in North China from 1981 to 2010. - Ecosystem Services 30: $172-180$. 
[102] Yirsaw, E., Wu, W., Shi, X., Temesgen, H., Bekele, B. (2017): Land use/land cover change modeling and the prediction of subsequent changes in ecosystem service values in a coastal area of China, the Su-Xi-Chang Region. - Sustainability 9(7): 1204.

[103] Zeleke, G., Hurni, H. (2001): Implications of land use and land cover dynamics for mountain resource degradation in the Northwestern Ethiopian highlands. - Mountain Research and Development 21(2): 184-191.

[104] Zhang, Z., Gao, J., Gao, Y. (2015): The influences of land use changes on the value of ecosystem services in Chaohu Lake Basin, China. - Environmental Earth Sciences 74(1): 385-395.

[105] Zhou, J., Sun, L., Zang, S., Wang, K., Zhao, J., Li, Z., Liu, X., Liu, X. (2017): Effects of the land use change on ecosystem service value. - Global Journal of Environmental Science and Management 3(2): 121-130. 